\title{
As Antimicrobial Agents: Synthesis, Structural Characterization and Molecular Docking study of Barbituric Acid Derivatives from Phenobarbital
}

Mahmood M. Fahad ( $\square$ mahmood.mohy.iku@atu.edu.iq)

Al-Furat Al-Awsat Technical University https://orcid.org/0000-0003-2405-7047

Nusrat Shafiq

Government College Women University Faisalabad

Uzma Arshad

Government College University Faisalabad

Ali Jabbar Radh

Alkafeel university

Research Article

Keywords: Barbituric acid, Phenobarbital, Cycloaddition reaction, Tetrazoline, Tetrazole

Posted Date: November 1st, 2021

DOI: https://doi.org/10.21203/rs.3.rs-1019035/v1

License: (c) (i) This work is licensed under a Creative Commons Attribution 4.0 International License.

Read Full License 


\title{
As Antimicrobial Agents: Synthesis, Structural Characterization and Molecular Docking study of Barbituric Acid Derivatives from Phenobarbital
}

\author{
Mahmood M. Fahad ${ }^{1, *}$, Nusrat Shafiq ${ }^{2}$ and Uzma Arshad ${ }^{2}$, Ali Jabbar Radh ${ }^{3}$ \\ ${ }^{1}$ Medical Laboratory Techniques Department, Kufa Technical Institute, Al-Furat Al-Awsat \\ Technical University, Kufa, Iraq. \\ ${ }^{2}$ Department of chemistry, Government College Women Uniersity Faisalabad-38000, \\ Pakistan. \\ ${ }^{3}$ Faculty of Pharmacy, Al-Kafeel University, Najaf, Iraq. \\ *Email: mahmood.mohy.iku@atu.edu.iq \\ Tel.: + 9647804181764
}

\begin{abstract}
In spite of phenobarbital has been used in various medical fields as hypnotics, anxiolytics, and anticonvulsants, it also contains active functional groups that can be reacted to form other products as dyes, polymers, antimicrobial and anti-antioxidants agents. A series of barbituric acid derivatives containing 1,2,3,4-Tetrazoline moiety were synthesized from phenobarbital. Phenobarbital 1 as raw starting material was reacted with acrylonitrile compound to give diacetonitrile derivative 2, this compound was treated in two ways, urea and thiourea to form barbituric acid derivatives containing oxadiazole and thiadiazole ring 3, 4 respectively. The Schiff bases derivatives $5,6_{(\mathrm{a}-\mathrm{c})}$ were synthesized from reacting the latter compounds with three aromatic aldehydes. In the final step, the barbituric acid derivatives containing 1,2,3,4Tetrazoline moiety $7,8_{\text {(a-c) }}$ were prepared by cycloaddition reaction between different Schiff bases derivatives and sodium azide. The compounds were characterized by Melting point, ${ }^{13} \mathrm{C}-\mathrm{NMR},{ }^{1} \mathrm{H}-\mathrm{NMR}$ and FTIR techniques. Also, the result compounds were tested against two kinds of bacteria and two kinds of fungi. Most of the prepared derivatives were showed a high and clear effect against different types of bacteria and fungi. Molecular docking of final barbituric acid derivatives $7,8_{(a, b)}$ were investigated with Molegro Virtual Docker (MVD).
\end{abstract}

Keywords; Barbituric acid, Phenobarbital, Cycloaddition reaction, Tetrazoline, Tetrazole.

\section{Introduction}

Due to their diverse biological effects, a significant number of barbituric acid derivatives have piqued the interest of the pharmaceutical community for more than a century [1]. Barbituric acids and its derivatives are organic substances which are used in pharmacology as hypnotics, sedatives, antihypertensive drugs, anesthetics, anticancer, anticonvulsant, antioxidants, antifungal agent, antibacterial, and Alpha-glycosidase enzyme inhibitors [2-7]. Chemically, via the donor-acceptor process of protons in the building-block structures of barbituric acid, the presence of five atoms (Three Oxygen and Two Nitrogen) with roles in coordination chemistry allows for the possible development and stability of supramolecular arrangements [8]. Barbituric acid can thus be defined as an organic building block that can behave intramolecularly and intermolecularly due to the presence of these $\mathrm{O}$ and $\mathrm{N}$ atoms [9]. Phenobarbital (PHB) or 5-ethyl, 5-phenyl barbituric acid as a starting material, is one of the most common barbituric acid derivatives. In their 1904 paper, Fischer and Dilthey listed phenobarbital compound as one of the compounds they discovered, Structure 1[10]. 
<smiles>CCC1(c2ccccc2)C(=O)NC(=O)NC1=O</smiles>

Structure 1. Phenobarbital Compound

In organic chemistry, Cycloaddition reactions are one of the most significant processes with synthetic and mechanistic importance. The simplicity of these cycloaddition reactions, as well as their exceptional stereochemistry, makes them useful [11]. 1,3-dipolar cycloaddition reactions have been commonly used in the synthesis of natural products and bioactive organic compounds, as well as in the construction of various five-membered heterocyclic. The majority of 1,3-dipolar compounds are heteroatom based diazoalkanes, azomethine ylides, azides, nitrile ylides, nitrile imines, nitrile oxides, nitrones, carbonyl ylides, and carbonyl imines [12]. Tetrazole and its derivatives have a wide spectrum of biological activities, including antimicrobial, antifungal, HCV (Hepatitis C virus) inhibitor, potent hypoglycemic agent, and cholinesterase inhibitors [13-17]. Tetrazoline or substituted tetrazoline compounds have just one isomer and one carbon atom, but the tetrazoline has two tautomers, Structure 2 [18].

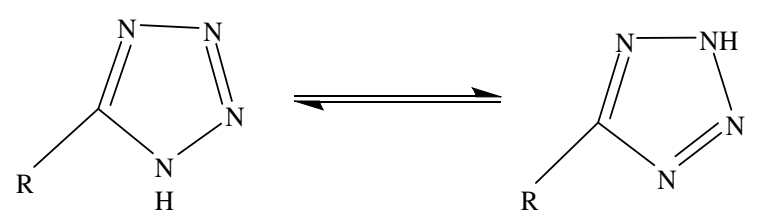

Structure 2. Two tautomers of tetrazole

\section{Experimental}

The chemical materials and solvents were supplied and purchased from BDH (England), Fluke RDH (Switzerland), and Merck (Germany) Companies, Baghdad city. The Electrothermal technique (SMP30) type was used to identify the melting points of the synthesized samples. The TLC test was measured to determine the progress of the reactions by using (glass TLC 1020 GS - Silica gel- 60). The synthesized compounds were characterized using (Shimadzu-8400S for IR; Kufa University, Bruker-75 MHZ and 400 MHZ for NMR; Teheran, Iran). Biological activities were measured by using petri dishes, Muller Hinton agar for bacteria test, potato agar for fungi test, and DMSO as solvent.

\subsection{Chemical Part}

2.1.1. Synthesis of 3,3'-(5-ethyl-2,4,6-trioxo-5-phenyldihydropyrimidine-1,3(2H,4H)-diyl) dipropanenitrile 2 [19]

In the presence of $(0.012 \mathrm{~mol})$ triethylamine, a mixture of $(0.006 \mathrm{~mol})$ phenobarbital 1 and $(0.012 \mathrm{~mol})$ of acrylonitrile was mixed with $(25 \mathrm{ML})$ of absolute ethanol. The contents were refluxed for $5 \mathrm{hrs}$. After that, the mixture was acidified by $(0.1 \mathrm{~N})$ of HCL to neutralize the mixture. The result product $(85 \%)$ was filtered, washed and re-crystallized from acetone. Melting point: $170-172{ }^{\circ} \mathrm{C}, \mathrm{R}_{\mathrm{f}}:$ : 0.55 , TLC (4:1, Benzene: Methanol).

FT-IR spectra $\left(v_{\max }\right): 2884-2972 \mathrm{~cm}^{-1}$ (Aliphatic CH), $2227 \mathrm{~cm}^{-1}(\mathrm{CN}), 1660 \mathrm{~cm}^{-1}(\mathrm{C}=\mathrm{O})$ Barbituric acid, ${ }^{1} \mathrm{H}-\mathrm{NMR}$ Spectrum (DMSO-d 6 ): $3.81 \delta \mathrm{ppm}\left(\mathrm{t}, 4 \mathrm{H}, 2 \mathrm{~N}-\mathrm{C}_{2}\right), 3.18 \delta \mathrm{ppm}(\mathrm{t}$, $4 \mathrm{H}, 2 \underline{\mathrm{C}}_{2}-\mathrm{CN}$ ), $2.28 \delta \mathrm{ppm}$ (q, $2 \mathrm{H}, \mathrm{CH}_{2}$ Barbituric acid), $0.88 \delta \mathrm{ppm}\left(\mathrm{t}, 3 \mathrm{H}, \mathrm{CH}_{3}\right.$ Barbituric 
acid), 7.28-7.48 $\delta$ ppm (m, 5H, Aromatic ring-H), ${ }^{13} \mathrm{C}-\mathrm{NMR}$ Spectrum (DMSO-d $\mathrm{d}_{6}$ ): $119.22 \delta$ $\operatorname{ppm}(2 \mathrm{CN}), 40.42 \delta \mathrm{ppm}\left(2 \mathrm{~N}-\underline{\mathrm{C}} \mathrm{H}_{2}\right), 16.14 \delta \mathrm{ppm}\left(2 \underline{\mathrm{CH}}_{2}-\mathrm{CN}\right), 150.23,172.45 \delta \mathrm{ppm}(3 \mathrm{C}=\mathrm{O})$, $124.83,128.48,140.23 \delta \mathrm{ppm}$ (C-Aromatic ring).

2.1.2. Synthesis of 1,3-bis(2-(5-amino-1,3,4-oxadiazol-2-yl)ethyl)-5-ethyl-5-phenylpyrimidine2,4,6(1H,3H,5H)-trione 3 [20]

The compound $2(0.006 \mathrm{~mol})$ with $(0.012 \mathrm{~mol})$ of urea were mixed in (20 ML) absolute ethanol, the acetic acid was added drop by drop to the mixture. The reaction after refluxing 12 hours was poured onto ice to give a white precipitate. The end result $(78 \%)$ was washed with water and re-crystallized from Acetone. Melting point: 203-205 ${ }^{\circ} \mathrm{C}, \mathrm{R}_{\mathrm{f}}$ : 0.47 , TLC (4:1, Benzene: Methanol).

FT-IR spectra $\left(v_{\max }\right)$ : 2738-2989 $\mathrm{cm}^{-1}$ (Aliphatic CH), $3381 \mathrm{~cm}^{-1}\left(\mathrm{NH}_{2}\right), 1544 \mathrm{~cm}^{-1}(\mathrm{C}-\mathrm{N})$, $1664 \mathrm{~cm}^{-1}(\mathrm{C}=\mathrm{O})$ Barbituric acid. $1281 \mathrm{~cm}^{-1}(\mathrm{C}-\mathrm{O}),{ }^{1} \mathrm{H}-\mathrm{NMR}$ Spectrum (DMSO-d $\left.{ }_{6}\right): 7.87 \delta$ ppm (s, 4H, 2NH $\left.\mathrm{NH}_{2}\right), 3.34 \delta \mathrm{ppm}\left(\mathrm{t}, 4 \mathrm{H}, 2 \mathrm{~N}-\underline{\mathrm{H}}_{2}\right), 2.67 \delta \mathrm{ppm}\left(\mathrm{t}, 4 \mathrm{H}, 2 \mathrm{C}_{2}\right.$-Oxidazole), 2.23 (q, 2H, $\mathrm{CH}_{2}$ Barbituric acid), 0.86 $\delta \mathrm{ppm}\left(\mathrm{t}, 3 \mathrm{H}, \mathrm{CH}_{3}\right.$ Barbituric acid), 7.24-7.47 $\delta \mathrm{ppm}(\mathrm{m}$, $5 \mathrm{H}$, Aromatic ring-H), ${ }^{13} \mathrm{C}-\mathrm{NMR}$ Spectrum (DMSO-d $\mathrm{d}_{6}$ ): $156.59 \delta \mathrm{ppm}(\mathrm{C}-5$ Oxadiazole), $163.61 \delta \mathrm{ppm}\left(2 \mathrm{C}-\mathrm{NH}_{2}\right), 43.65 \delta \mathrm{ppm}\left(2 \mathrm{~N}-\underline{\mathrm{CH}}_{2}\right), 22.63 \delta \mathrm{ppm}\left(2 \mathrm{CH}_{2}\right.$-Oxidazole $), 153.84$, $175.42 \delta \mathrm{ppm}(3 \mathrm{C}=\mathrm{O}), 122.45,125.01,143.60 \delta \mathrm{ppm}$ (C-Aromatic ring).

\subsubsection{Synthesis of1,3-bis(2-(5-amino-1,3,4-thiadiazol-2-yl)ethyl)-5-ethyl-5-phenylpyrimidine-} 2,4,6(1H,3H,5H)-trione 4 [2O]

As the previous compound $3, \mathrm{~A}(0.006 \mathrm{~mol})$ of compound 2 and $(0.012 \mathrm{~mol})$ of thiourea were dissolved in (20 ML) of absolute ethanol. The acid (acetic acid) was added to the mixture. The reaction was refluxed for $12 \mathrm{hrs}$. The result precipitate (82\%) was filtered, washed and re-crystallized from Acetone. Melting point: $198-200{ }^{\circ} \mathrm{C}, \mathrm{R}_{\mathrm{f}}$ : 0.5, TLC (4:1, Benzene: Methanol).

FT-IR spectra $\left(v_{\max }\right)$ : 2738-2989 $\mathrm{cm}^{-1}$ (Aliphatic CH), $3363 \mathrm{~cm}^{-1}\left(\mathrm{NH}_{2}\right), 1541 \mathrm{~cm}^{-1}(\mathrm{C}-\mathrm{N})$, $1669 \mathrm{~cm}^{-1}(\mathrm{C}=\mathrm{O})$ Barbituric acid. $1274 \mathrm{~cm}^{-1}(\mathrm{C}-\mathrm{O}),{ }^{1} \mathrm{H}-\mathrm{NMR}$ Spectrum (DMSO-d $\left.{ }_{6}\right): 7.85 \delta$

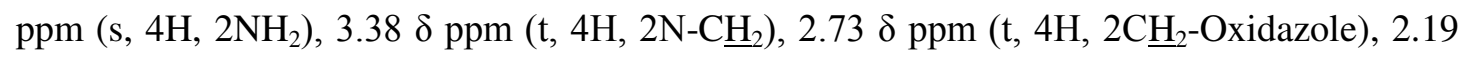
(q, $2 \mathrm{H}, \mathrm{CH}_{2}$ Barbituric acid), $0.89 \delta \mathrm{ppm}\left(\mathrm{t}, 3 \mathrm{H}, \mathrm{CH}_{3}\right.$ Barbituric acid), 7.20-7.52 $\delta \mathrm{ppm}(\mathrm{m}$, $5 \mathrm{H}$, Aromatic ring-H), ${ }^{13} \mathrm{C}-\mathrm{NMR}$ Spectrum (DMSO-d $\left.\mathrm{d}_{6}\right): 150.42 \delta$ ppm(C-5 Oxadiazole), $166.34 \delta \mathrm{ppm}\left(2 \mathrm{C}-\mathrm{NH}_{2}\right), 41.22 \delta \mathrm{ppm}\left(2 \mathrm{~N}-\underline{\mathrm{CH}_{2}}\right), 20.37 \delta \mathrm{ppm}\left(2 \mathrm{C}_{2}\right.$-Oxidazole $), 155.72$, $173.44 \delta \mathrm{ppm}(3 \mathrm{C}=\mathrm{O}), 119.32,128.27,145.46 \delta \mathrm{ppm}$ (C-Aromatic ring).

\subsubsection{General Synthesis of Schiff base derivatives 5, 6(a-c) [21-23]}

A mixture of (0.006 mol) compounds (3 or 4) and (0.012 mol) of different aromatic aldehydes (4-(dimethylamino)benzaldehyde, 4-Bromobenzaldehyde and 2,4Dichlorobenzaldehyde) were mixed with (20 ML) absolute ethanol. To the mixture, (3-4) drops of glacial acetic acid were added. For 6 hrs, the reaction was stirred and refluxed. The final products were washed with water, dried, and re-crystallized from hot ethanol, Table1.

FT-IR spectra $\left(v_{\max }\right)$ for $5 \mathrm{a}: 1630 \mathrm{~cm}^{-1}(\mathrm{C}=\mathrm{N}$ imine $), 1550 \mathrm{~cm}^{-1}(\mathrm{C}=\mathrm{C}$ aromatic). FT-IR spectra $\left(v_{\max }\right)$ for $5 \mathrm{~b}: 1643 \mathrm{~cm}^{-1}(\mathrm{C}=\mathrm{N}$ imine $), 1547 \mathrm{~cm}^{-1}\left(\mathrm{C}=\mathrm{C}\right.$ aromatic). FT-IR spectra $\left(v_{\max }\right)$ for $5 \mathrm{c}$ : $1635 \mathrm{~cm}^{-1}$ ( $\mathrm{C}=\mathrm{N}$ imine), $1556 \mathrm{~cm}^{-1}(\mathrm{C}=\mathrm{C}$ aromatic $)$.

${ }^{1} \mathrm{H}-\mathrm{NMR}$ Spectrum for $5 \mathrm{a}\left(\mathrm{DMSO}_{\mathrm{d}}\right): 8.53 \delta \mathrm{ppm}(\mathrm{s}, 1 \mathrm{H}, 2 \mathrm{CH}=\mathrm{N}), 3.16 \delta \mathrm{ppm}(\mathrm{s}, 3 \mathrm{H}, 2 \mathrm{~N}-$ $\mathrm{CH}_{3}$ ), 6.2-7.6 $\delta \mathrm{ppm}\left(\mathrm{m}, 4 \mathrm{H}\right.$, Aromatic ring-H), ${ }^{1} \mathrm{H}-\mathrm{NMR}$ Spectrum for $5 \mathrm{~b}$ (DMSO-d $\left.\mathrm{D}_{6}\right): 8.66 \delta$ ppm $(\mathrm{s}, 1 \mathrm{H}, 2 \mathrm{CH}=\mathrm{N}), 6.5-7.9 \delta \mathrm{ppm}\left(\mathrm{m}, 4 \mathrm{H}\right.$, Aromatic ring-H), ${ }^{1} \mathrm{H}-\mathrm{NMR}$ Spectrum for $5 \mathrm{c}$ $\left(\mathrm{DMSO}_{\mathrm{d}}\right)$ : $8.45 \delta \mathrm{ppm}(\mathrm{s}, 1 \mathrm{H}, 2 \mathrm{CH}=\mathrm{N}), 6.8-7.7 \delta \mathrm{ppm}(\mathrm{m}, 4 \mathrm{H}$, Aromatic ring- $\mathrm{H})$, 
${ }^{13} \mathrm{C}-\mathrm{NMR}$ Spectrum (DMSO-d $\left.{ }_{6}\right)$ for $5 \mathrm{a}: 160.55 \delta \mathrm{ppm}(\mathrm{CH}=\mathrm{N}), 40.72 \delta \mathrm{ppm}\left(\mathrm{N}-\mathrm{CH}_{3}\right),{ }^{13} \mathrm{C}-$ NMR Spectrum (DMSO-d $\mathrm{d}_{6}$ ) for $5 \mathrm{~b}: 161.05 \delta \mathrm{ppm}(\mathrm{CH}=\mathrm{N}) .{ }^{13} \mathrm{C}-\mathrm{NMR}$ Spectrum $\left(\mathrm{DMSO}-\mathrm{d}_{6}\right)$ for $5 \mathrm{c}: 160.87 \delta \mathrm{ppm}(\mathrm{CH}=\mathrm{N})$.

Table 1. General formula, M.wt, Reaction yield, M.p and $\mathrm{R}_{f}$ of compounds $\mathbf{5}, \mathbf{6}_{(\mathrm{a}-\mathrm{c})}$

\begin{tabular}{cccccc}
\hline Comp. & General formula & M.wt glmol & Yield \% & M.P ${ }^{\mathbf{0}} \mathbf{C}$ & $\mathbf{R}_{\boldsymbol{f}}$ \\
\hline $\mathbf{5 a}$ & $\mathrm{C}_{38} \mathrm{H}_{40} \mathrm{~N}_{10} \mathrm{O}_{5}$ & 716.79 & $75 \%$ & $140-142$ & 0.53 \\
$\mathbf{5 b}$ & $\mathrm{C}_{34} \mathrm{H}_{28} \mathrm{Br}_{2} \mathrm{~N}_{8} \mathrm{O}_{5}$ & 788.44 & $83 \%$ & $207-209$ & 0.55 \\
$\mathbf{5 c}$ & $\mathrm{C}_{34} \mathrm{H}_{26} \mathrm{Cl}_{4} \mathrm{~N}_{8} \mathrm{O}_{5}$ & 768.43 & $80 \%$ & $153-155$ & 0.63 \\
$\mathbf{6 a}$ & $\mathrm{C}_{38} \mathrm{H}_{40} \mathrm{~N}_{10} \mathrm{O}_{3} \mathrm{~S}_{2}$ & 748.92 & $77 \%$ & $159-161$ & 0.74 \\
$\mathbf{6 b}$ & $\mathrm{C}_{34} \mathrm{H}_{28} \mathrm{Br}_{2} \mathrm{~N}_{8} \mathrm{O}_{3} \mathrm{~S}_{2}$ & 820.58 & $78 \%$ & $195-197$ & 0.46 \\
$\mathbf{6 c}$ & $\mathrm{C}_{34} \mathrm{H}_{26} \mathrm{Cl}_{4} \mathrm{~N}_{8} \mathrm{O}_{3} \mathrm{~S}_{2}$ & 800.56 & $85 \%$ & $166-169$ & 0.49 \\
\hline
\end{tabular}

2.1.5. General Synthesis of Barbituric acid Derivatives containing 1,2,3,4-Tetrazoline moiety 7, 8(a-c) [24-25]

In the DMF solvent, the compounds $7,8_{(\mathrm{a}-\mathrm{c})}$ were prepared from reaction Schiff base derivatives $5,6_{\text {(a-c) }}$, two moles of sodium azide, and catalytic agents (cupper chloride (I) with sodium ascorbate. At the room temperature, the reaction was stirred for 24 hrs. the reaction progress was followed by TLC technique (4:1, Benzene: Methanol). The results were filtered, dried, washed, and re-crystallized with ethanol, Table 2.

FT-IR spectra $\left(v_{\max }\right)$ for 7a: Disappearance $(\mathrm{C}=\mathrm{N}$ imine $)$ group, $1563 \mathrm{~cm}^{-1}(\mathrm{C}=\mathrm{C}$ aromatic $)$, $1545 \mathrm{~cm}^{-1}(\mathrm{C}=\mathrm{N})$ Oxadazole ring, $1147 \mathrm{~cm}^{-1}(\mathrm{C}-\mathrm{N}), 1058 \mathrm{~cm}^{-1}(\mathrm{~N}-\mathrm{N}), 1679 \mathrm{~cm}^{-1}(\mathrm{C}=\mathrm{O})$ Barbituric acid. FT-IR spectra $\left(v_{\max }\right)$ for $7 \mathrm{~b}$ : Disappearance $(\mathrm{C}=\mathrm{N}$ imine $), 1567 \mathrm{~cm}^{-1}(\mathrm{C}=\mathrm{C}$ aromatic), $1556 \mathrm{~cm}^{-1}(\mathrm{C}=\mathrm{N})$ Oxadiazole ring, $1144 \mathrm{~cm}^{-1}(\mathrm{C}-\mathrm{N}), 1067 \mathrm{~cm}^{-1}(\mathrm{~N}-\mathrm{N}), 1685 \mathrm{~cm}^{-1}$ $(\mathrm{C}=\mathrm{O})$ Barbituric acid. FT-IR spectra $\left(\mathrm{v}_{\max }\right)$ for $7 \mathrm{c}$ : Disappearance $(\mathrm{C}=\mathrm{N}$ imine $), 1574 \mathrm{~cm}^{-1}$ $\left(\mathrm{C}=\mathrm{C}\right.$ aromatic), $1539 \mathrm{~cm}^{-1}(\mathrm{C}=\mathrm{N})$ Oxadiazole ring, $1172 \mathrm{~cm}^{-1}(\mathrm{C}-\mathrm{N}), 1076 \mathrm{~cm}^{-1}(\mathrm{~N}-\mathrm{N}), 1668$ $\mathrm{cm}^{-1}(\mathrm{C}=\mathrm{O})$ Barbituric acid.

${ }^{1} \mathrm{H}-\mathrm{NMR}$ Spectrum for 7a (DMSO-d $\left.\mathrm{d}_{6}\right)$ : Disappearance $(\mathrm{CH}=\mathrm{N}), 5.09 \delta \mathrm{ppm}(\mathrm{s}, 2 \mathrm{H}, 2 \mathrm{CH})$, $3.40 \delta \mathrm{ppm}\left(\mathrm{s}, 3 \mathrm{H}, 2 \mathrm{~N}-\mathrm{CH}_{3}\right), 6.5-7.3 \delta \mathrm{ppm}\left(\mathrm{m}, 4 \mathrm{H}\right.$, Aromatic ring-H), ${ }^{1} \mathrm{H}-\mathrm{NMR}$ Spectrum for $7 \mathrm{~b}\left(\mathrm{DMSO}-\mathrm{d}_{6}\right)$ : Disappearance $(\mathrm{s}, 1 \mathrm{H}, 2 \mathrm{CH}=\mathrm{N}), 5.06 \delta \mathrm{ppm}(\mathrm{s}, 2 \mathrm{H}, 2 \mathrm{CH}), 6.5-7.6 \delta \mathrm{ppm}$ (m, 4H, Aromatic ring-H), ${ }^{1} \mathrm{H}-\mathrm{NMR}$ Spectrum for $7 \mathrm{c}\left(\right.$ DMSO- $\left._{6}\right)$ : Disappearance $(\mathrm{s}, 1 \mathrm{H}$, $2 \mathrm{CH}=\mathrm{N}), 5.12 \delta \mathrm{ppm}(\mathrm{s}, 2 \mathrm{H}, 2 \mathrm{CH}), 6.4-7.2 \delta \mathrm{ppm}(\mathrm{m}, 4 \mathrm{H}$, Aromatic ring-H),

${ }^{13} \mathrm{C}-\mathrm{NMR}$ Spectrum $\left(\mathrm{DMSO}_{6}\right)$ for $7 \mathrm{a}$ : Disappearance $(\mathrm{CH}=\mathrm{N}), 88.23 \quad \delta \mathrm{ppm}$ $(\mathrm{CH})$ Tetrazoline ring, $40.18 \delta \mathrm{ppm}\left(\mathrm{N}-\underline{\mathrm{CH}}_{3}\right), 112.34,127.32,136.35,151.53 \delta \mathrm{ppm}(\mathrm{C}-$ Aromatic ring). ${ }^{13} \mathrm{C}-\mathrm{NMR}$ Spectrum $\left(\mathrm{DMSO}-\mathrm{d}_{6}\right)$ for $7 \mathrm{~b}$ : Disappearance $(\mathrm{CH}=\mathrm{N}), 87.89 \delta \mathrm{ppm}$ $(\mathrm{CH})$ Tetrazoline ring, 111.64, 128.92, 136.28, $153.26 \delta \mathrm{ppm}$ (C-Aromatic ring). ${ }^{13} \mathrm{C}-\mathrm{NMR}$ Spectrum $\left(\right.$ DMSO- $\left._{6}\right)$ for $7 \mathrm{c}$ : Disappearance $(\mathrm{CH}=\mathrm{N}), 85.03 \delta \mathrm{ppm}(\mathrm{CH})$ Tetrazoline ring, $112.78,128.05,135.97,151.89 \delta \mathrm{ppm}$ (C-Aromatic ring).

${ }^{1} \mathrm{H}-\mathrm{NMR}$ Spectrum for 8a (DMSO-d $\mathrm{d}_{6}$ ): Disappearance (s, $\left.1 \mathrm{H}, 2 \mathrm{CH}=\mathrm{N}\right), 5.13 \delta \mathrm{ppm}(\mathrm{s}, 2 \mathrm{H}, 2$ $\mathrm{CH}), 3.34 \delta \mathrm{ppm}\left(\mathrm{s}, 3 \mathrm{H}, 2 \mathrm{~N}-\mathrm{CH}_{3}\right), 6.9-7.6 \delta \mathrm{ppm}\left(\mathrm{m}, 4 \mathrm{H}\right.$, Aromatic ring-H), ${ }^{1} \mathrm{H}-\mathrm{NMR}$ Spectrum for $8 \mathrm{~b}\left(\mathrm{DMSO}_{-} \mathrm{d}_{6}\right)$ : Disappearance $(\mathrm{s}, 1 \mathrm{H}, 2 \mathrm{CH}=\mathrm{N}), 5.23 \delta \mathrm{ppm}(\mathrm{s}, 2 \mathrm{H}, 2 \mathrm{CH}), 6.8-$ 
$7.3 \delta \mathrm{ppm}\left(\mathrm{m}, 4 \mathrm{H}\right.$, Aromatic ring-H), ${ }^{1} \mathrm{H}-\mathrm{NMR}$ Spectrum for $8 \mathrm{c}\left(\mathrm{DMSO}_{\mathrm{d}} \mathrm{d}_{6}\right)$ : Disappearance $(\mathrm{s}, 1 \mathrm{H}, 2 \mathrm{CH}=\mathrm{N}), 5.16 \delta \mathrm{ppm}(\mathrm{s}, 2 \mathrm{H}, 2 \mathrm{CH}), 6.9-7.3 \delta \mathrm{ppm}(\mathrm{m}, 4 \mathrm{H}$, Aromatic ring- $\mathrm{H})$,

${ }^{13} \mathrm{C}-\mathrm{NMR}$ Spectrum (DMSO-d $\left.\mathrm{d}_{6}\right)$ for 8a: Disappearance $(\mathrm{CH}=\mathrm{N}), 89.41 \delta \mathrm{ppm}(\mathrm{CH})$ Tetrazoline ring, $40.45 \delta \mathrm{ppm}\left(\mathrm{N}-\mathrm{CH}_{3}\right), 112.35,128.51,136.63,150.42 \delta \mathrm{ppm}$ (C-Aromatic ring). ${ }^{13} \mathrm{C}-\mathrm{NMR}$ Spectrum $\left(\mathrm{DMSO}_{6}\right)$ for $8 \mathrm{~b}$ : Disappearance $(\mathrm{CH}=\mathrm{N}), 88.94 \delta \mathrm{ppm}(\mathrm{CH})$ Tetrazoline ring, 112.34, 127.54, 135.86, $152.99 \delta \mathrm{ppm}$ (C-Aromatic ring). ${ }^{13} \mathrm{C}-\mathrm{NMR}$ Spectrum $\left(\right.$ DMSO- $\left.\mathrm{d}_{6}\right)$ for $8 \mathrm{c}$ : Disappearance $(\mathrm{CH}=\mathrm{N}), 86.34 \delta \mathrm{ppm}(\mathrm{CH})$ Tetrazoline ring, $112.39,128.52,136.02,152.29 \delta \mathrm{ppm}$ (C-Aromatic ring).

Table 2. General formula, M.Wt, Reaction yield, M.p and $\mathrm{R}_{f}$ of compounds 7, $8_{(\mathrm{a}-\mathrm{c})}$

\begin{tabular}{cccccc}
\hline Comp. & General formula & M.Wt g\mol & Yield \% & M.P ${ }^{\mathbf{0}} \mathbf{C}$ & $\mathbf{R}_{\boldsymbol{f}}$ \\
\hline $\mathbf{7 a}$ & $\mathrm{C}_{38} \mathrm{H}_{40} \mathrm{~N}_{16} \mathrm{Na}_{2} \mathrm{O}_{5}$ & 846.81 & $70 \%$ & $174-176$ & 0.65 \\
$\mathbf{7 b}$ & $\mathrm{C}_{34} \mathrm{H}_{28} \mathrm{Br}_{2} \mathrm{~N}_{14} \mathrm{Na}_{2} \mathrm{O}_{5}$ & 918.46 & $74 \%$ & $222-224$ & 0.63 \\
$\mathbf{7 c}$ & $\mathrm{C}_{34} \mathrm{H}_{26} \mathrm{Cl}_{4} \mathrm{~N}_{14} \mathrm{Na}_{2} \mathrm{O}_{5}$ & 898.45 & $80 \%$ & $165-167$ & 0.57 \\
$\mathbf{8 a}$ & $\mathrm{C}_{38} \mathrm{H}_{40} \mathrm{~N}_{16} \mathrm{Na}_{2} \mathrm{O}_{3} \mathrm{~S}_{2}$ & 878.94 & $76 \%$ & $156-158$ & 0.52 \\
$\mathbf{8 b}$ & $\mathrm{C}_{34} \mathrm{H}_{28} \mathrm{Br}_{2} \mathrm{~N}_{14} \mathrm{Na}_{2} \mathrm{O}_{3} \mathrm{~S}_{2}$ & 950.60 & $71 \%$ & $206-208$ & 0.68 \\
$\mathbf{8 c}$ & $\mathrm{C}_{34} \mathrm{H}_{26} \mathrm{Cl}_{4} \mathrm{~N}_{14} \mathrm{Na}_{2} \mathrm{O}_{3} \mathrm{~S}_{2}$ & 930.58 & $79 \%$ & $177-178$ & 0.66 \\
\hline
\end{tabular}

\subsection{Biological part}

The solutions were diluted by dissolving the chemically prepared compounds with dimethyl sulfoxide solvent to $\left(0.05 \mathrm{gm}\right.$. MLL). After the sterilization process of petri dishes at $140{ }^{\circ} \mathrm{C}$ for one hour, every Petri dish was punctured into three equal holes ( $6 \mathrm{~mm}$ diameter) by a Cork borer. The dilute prepared compounds were placed in the holes for 24 hours at $37{ }^{0} \mathrm{C}$. Finally, the inhibition zones were measured by the ruler and compared the results with stander compounds [26-28]. The medium Muller Hinton Agar and potato dextrose agar were added to the petri dish as an active medium for the growth of the bacterial and fungal types respectively. The prepared compounds were tested against two kinds of bacteria $(($ Staphylococcus aureus $(+)$ \& Escherichia coli (-)) and two kinds of fungi (Aspergillus flavus \& Candida Albicans).

\subsection{Molecular docking Methodology}

Virtual molecular docking studies were used to investigate the inhibitory potential of produced compounds [29]. Virtual screening was performed using Molegro Virtual Docker (MVD), which was installed on an Intel Core i7 9700k processor with 120 GB SSD, 1 TB hard drive, and an NVIDA GeForce GTX 1050 graphics card [30, 31].

\subsection{Preparation of Ligand}

Following characterization, all synthesized structures were drawn using ChemDraw Professional 19.1 (PerkinElmer Inc, USA), and bond length and energy minimization were run on Chem3D Ultra 19.1.0.8 with the MMFF94 force field and imported to the MVD interface in mol2 format $[32,33]$.

\subsection{Homology Modelling}

The protein sequence of Aspergillus flavus DNA-dependent RNA polymerase (RNAP) was retrieved from the NCBI database [34]. It was sent to the automated modeling website MODWEB, which was a comparative protein modeling web service for generating protein 
sequence modeling of RNAP by comparing the sequence to a template protein from Schizosaccharomyces pombe (PDB ID 3h0g) [35]. After computations, the theoretically modelled structure was evaluated and uploaded to MVD for docking [36], Table 3.

\subsection{Preparation of target protein crystal}

Protein 3D crystal structure was retrieved from the URL (http://www.rscb.org/pdb) [37-38]. Criteria for the selection of protein was based on the resolution greater than $1.5 \mathrm{~A}$ and containing the gene code of same bacterial and fungal specie, whose inhibition was required [39]. Protein co-crystal structure of same bacterial and fungal species were retrieved from PDB site which was also lined up for in vitro activities [36]. Table 3, depict the summary of proteins utilized in molecular docking [40]. Discovery studio visualizer was used for removing solvent/water molecules, along with heteroatom removal. As MVD executed the docking into active sites of protein structure, therefore extra chains were removed from protein $[33,36,39]$. Binding site sphere was generated, and protein was imported to MVD graphical interface. Surface was created and by using detects cavity preparation tools cavities were generated [41].

Table 3. Summary of protein used for molecular docking by MVD

\begin{tabular}{|l|l|l|}
\hline Organism & PDB ID & Molecule \\
\hline Staphlococcus aureus & $1 \mathrm{ad} 4$ & Dihydropteroate synthase \\
\cline { 2 - 3 } & $3 \mathrm{ttz}$ & Topoisomerase ATPase inhibitor \\
\hline Escherichia coli & $6 \mathrm{f} 86$ & $\begin{array}{l}\text { E. coli } \text { DNA Gyrase in complex with pyridine-3- } \\
\text { carboxamide }\end{array}$ \\
\cline { 2 - 3 } & $1 \mathrm{kzn}$ & $\begin{array}{l}\text { DNA gyrase in complex with coumarin based } \\
\text { inhibitor }\end{array}$ \\
\hline Aspergillus fumigatus & $6 \mathrm{drs}$ & $\begin{array}{l}\text { Dihydrofolate reductase (DHFR) complex with small } \\
\text { inhibitor }\end{array}$ \\
\cline { 2 - 3 } & $\begin{array}{l}\text { Homology } \\
\text { modelled }\end{array}$ & DNA dependent RNA polymerase \\
\hline Candida albican & 1 ai9 & C. albicans dihydrofolate reductase \\
\cline { 2 - 3 } & 4 hof & Dihydrofolate reductase \\
\hline
\end{tabular}

\subsection{Molecular Docking and Scoring Function Assessment}

Molegro Virtual Docker has user friendly graphical interface and relies on differential algorithm, which measures the protein-ligand interaction in the form of functional factor Rerank score for best docked pose $[42,43]$. While total energy of interaction between proteinligand is measured in the form of MolDock score [44], based on PLP (pairwise linear potential) [33]. Grid resolution for docking was fixed to 0.30A, and binding site center coordinates was selected from user defined cavity 1 parameters [37]. Maximum iteration to 2000 and 50 maximum population size [29,30]. Discovery Studio Visualizer was used for generation of 3D and 2D protein-ligand interactions [31, 45]. 


\section{Results and Discussion}

\subsection{Chemistry}

The main goal of the study is to prepare and characterize new barbituric acid derivatives that contain tetrazoline moiety, which is an active moiety in pharmaceutical compounds. The first step involved preparing a 3,3'-(5-ethyl-2,4,6-trioxo-5-phenyldihydropyrimidine-1,3(2H,4H)diyl)dipropanenitrile from the sreaction of phenobarbital with acrylonitrile in the presence of triethylamine as base catalyst, Scheme 1 .<smiles>CCC1(c2ccccc2)C(=O)NC(=O)NC1=O</smiles><smiles>CCCCC</smiles><smiles>CCC1(c2ccccc2)C(=O)N(CCC#N)C(=O)N(CCC#N)C1=O</smiles>

Scheme 1. Synthesis of diacetonitrile derivative

According to the anti-Markovnikov rule, the N-H group is added to the carbon-carbon of an alkene during the hydroamination reaction of an inactivated alkene. FT-IR Spectrum, the $(\mathrm{CN})$ as a distinct group was observed at $2227 \mathrm{~cm}^{-1}$. While in the ${ }^{1} \mathrm{H}-\mathrm{NMR}$, the peaks were observed at $3.50 \delta \mathrm{ppm}$ for $\left(\mathrm{N}-\mathrm{CH}_{2}\right)$ and $3.15 \delta \mathrm{ppm}$ for $\left(\mathrm{CH}_{2}-\mathrm{CN}\right) \cdot{ }^{13} \mathrm{C}-\mathrm{NMR}$ Spectrum was gave $119.22 \delta \mathrm{ppm}$ for $(\mathrm{CN}), 40.42 \delta \mathrm{ppm}$ for $\left(\mathrm{N}^{\left.-\mathrm{CH}_{2}\right)}\right.$ and $16.14 \delta \mathrm{ppm}$ for $\left(\mathrm{CH}_{2}-\mathrm{CN}\right)$. Barbituric acid derivatives containing 1,3,4-Oxadiazole and 1,3,4-Thiadiazole ring 3, 4 were formed by reacting diacetonitrile derivative 2 with urea and thiourea. The mechanism of the reaction is similar in both steps; the difference is in the oxygen and sulfur atoms. The $\left(\mathrm{NH}_{2}\right)$ group in FTIR was notified at $3381 \mathrm{~cm}^{-1}$ and $3363 \mathrm{~cm}^{-1}$. In ${ }^{1} \mathrm{H}-\mathrm{NMR}$, this compounds were gave the peaks: 7.87-7.85 $\delta \mathrm{ppm}$ for $\left(\mathrm{NH}_{2}\right), 3.34-3.38 \delta \mathrm{ppm}$ for $\left(\mathrm{N}-\mathrm{C}_{2}\right), 2.67-2.73 \delta \mathrm{ppm}$ for $\left(\mathrm{CH}_{2}\right.$-Oxidazole). These are clear guides to form the compounds 3, 4, Scheme 2.

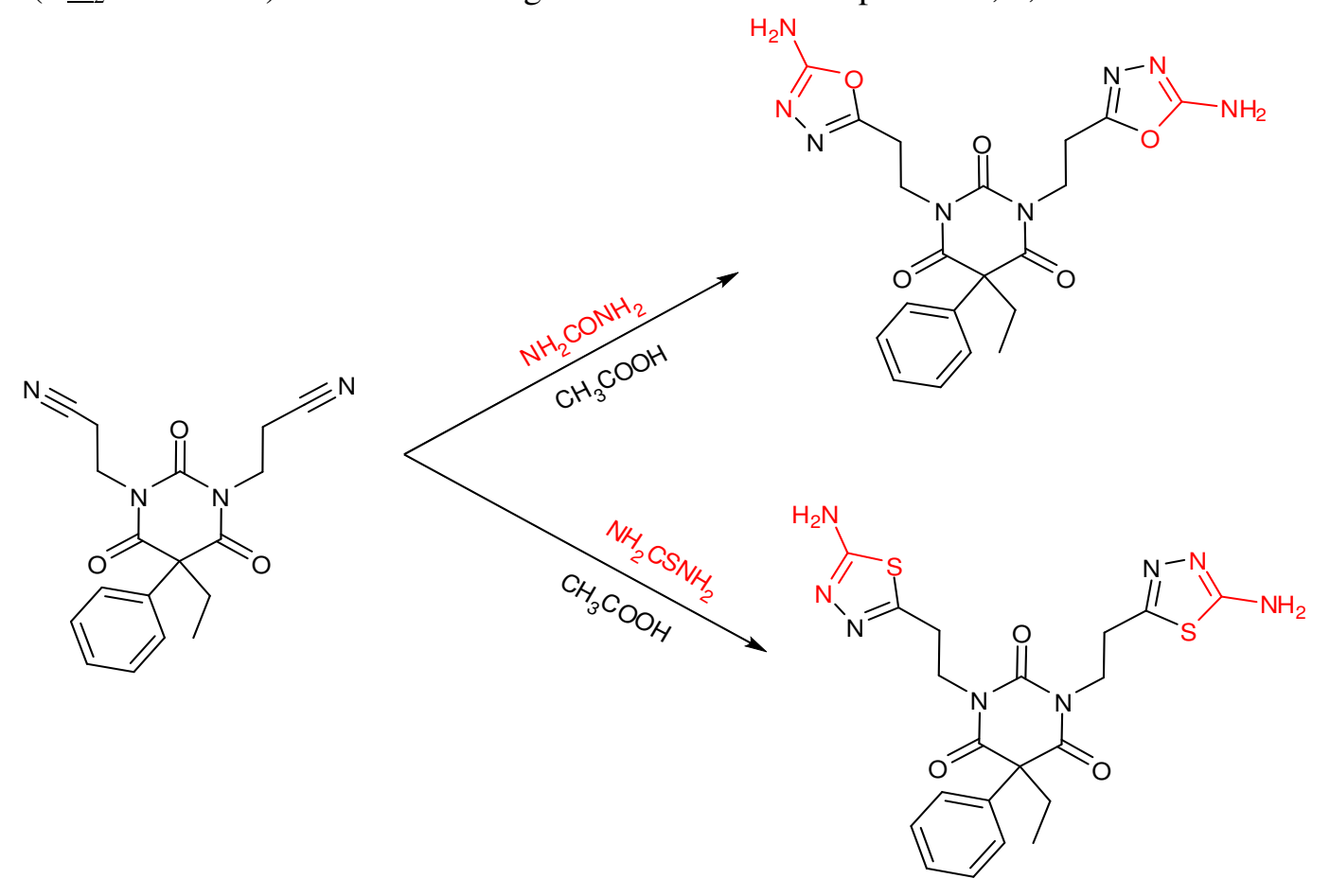


Scheme 2. Synthesis of Barbituric acid containing Oxadiazole and Thiadiazole ring

With drops of glacial acetic acid as a catalyst, the compounds 3 and 4 interact with various aldehydes such as (4-(dimethylamino) benzaldehyde, 4-Bromobenzaldehyde, and 2,4Dichlorobenzaldehyde). In the Schiff base reactions 5, 6, the distinguishing group in SchiffBase reactions is $(\mathrm{C}=\mathrm{N})$. The FT-IR peaks at $1630 \mathrm{~cm}^{-1}, 1643 \mathrm{~cm}^{-1}$, and $1635 \mathrm{~cm}^{-1}$ corresponded to the $(\mathrm{C}=\mathrm{N}$ imine $)$ group respectively. The $(\mathrm{CH}=\mathrm{N})$ was detected as a single in the ${ }^{1} \mathrm{H}-\mathrm{NMR}$ spectrum at $8.53 \mathrm{ppm}, 8.66 \mathrm{ppm}$, and $8.45 \mathrm{ppm}$. The $(\mathrm{CH}=\mathrm{N})$ was found at $160.55 \mathrm{ppm}, 161.05 \mathrm{ppm}$, and $160.87 \mathrm{ppm}$, respectively. While, in the ${ }^{13} \mathrm{C}-\mathrm{NMR}$ spectrum, the $(\mathrm{CH}=\mathrm{N})$ group was noticed at $160.55,161.05,160.87 \delta \mathrm{ppm}$ respectively, Scheme 3 .

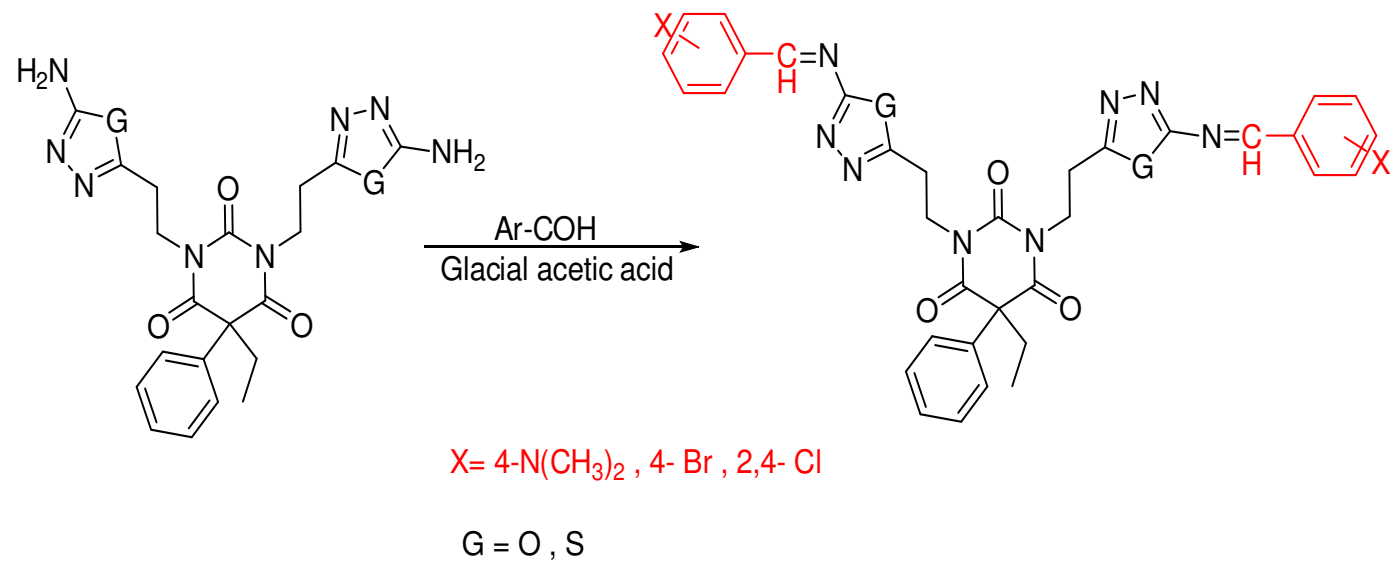

Scheme 3. Synthesis of Schiff bases derivatives

In the final step, the dipolarophile products from the Schiff bases were reacted with the 1,3dipole(sodium azide) by [3+2] cycloaddition reaction in the presence of catalysts as copper chloride $\mathrm{Cu}$ (I) and sodium ascorbate to form barbituric acid derivatives containing 1,2,3,4Tetrazoline moiety $7,8_{\text {(a-c) }}$. It is noticed that the imine $(\mathrm{C}=\mathrm{N})$ and azide $\left(-\mathrm{N}_{3}\right)$ groups disappear from Schiff bases and sodium azide spectra with new peaks are formed, Scheme 4.

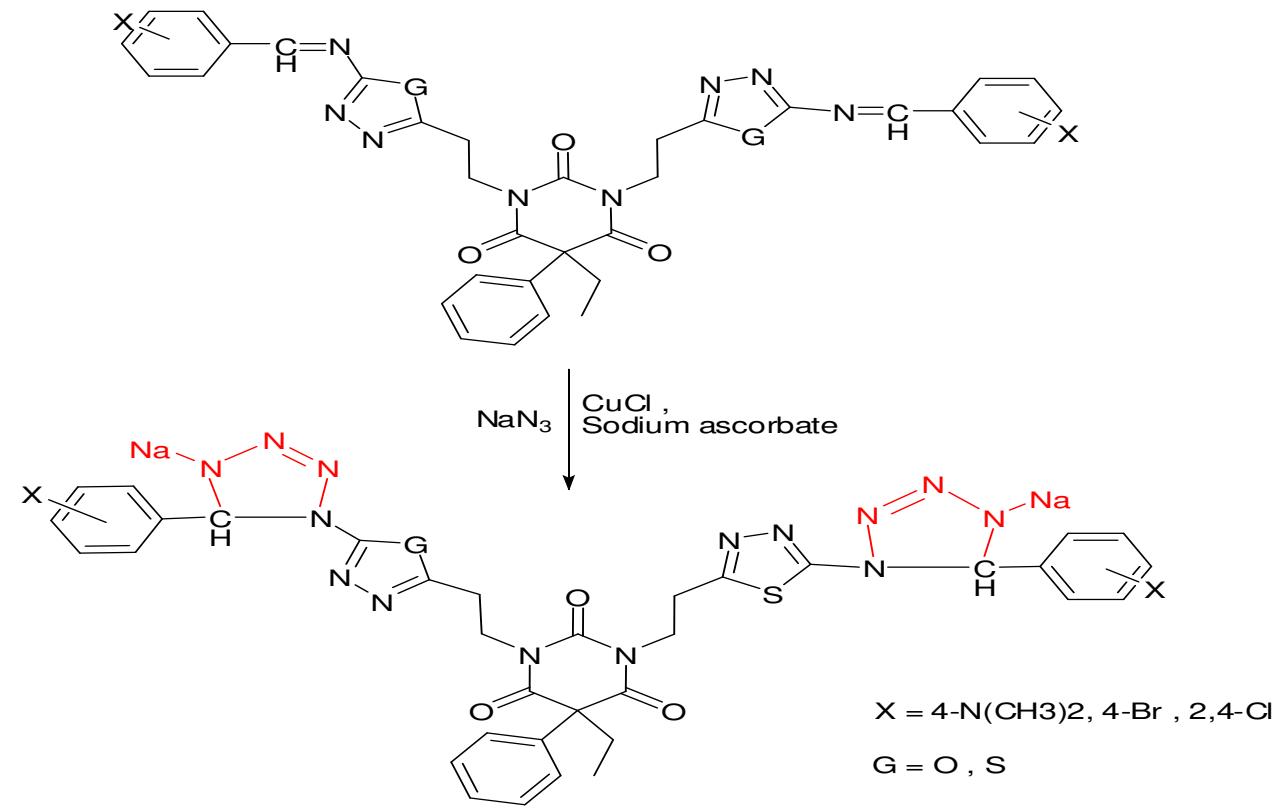


Scheme 4. Synthesis of barbituric acid derivatives

\subsection{Biological Activity in vitro}

The main goal of the work is the results of the applications of the prepared compounds; the tetrazoline derivatives have many applications in the field of medicine. From this point, these new derivatives were prepared to give high efficacy against bacteria and fungi types. The chemical prepared derivatives $7,8(\mathrm{a}, \mathrm{b})$ were examined against two kinds of bacteria ((Staphylococcus aureus $(+)$ \& Escherichia coli (-)) and two kinds of fungi (Aspergillus flavus \& Candida Albicans) by using Muller Hinton Agar and Potato Dextrose Agar. The biological results of prepared compounds with standard compounds are recorded in the following table 4 and figure 1.

Table 3. Antimicrobial test of some prepared compounds $\mathbf{7 ,} \mathbf{8}_{(\mathbf{a}, \mathbf{b})}$

\begin{tabular}{|c|c|c|c|c|}
\hline \multirow{2}{*}{ Sample } & \multicolumn{2}{|c|}{ Antibacterial } & \multicolumn{2}{c|}{ Antifungal } \\
\cline { 2 - 5 } & S. aureus & E. coli & A. flavus & C. Albicans \\
\hline Phenobarbital & + & + & - & - \\
\hline 7a & ++ & ++ & +++ & +++ \\
\hline 7b & - & - & +++ & +++ \\
\hline 8a & ++ & ++ & +++ & +++ \\
\hline 8b & ++ & ++ & +++ & +++ \\
\hline Ampicillin & +++ & +++ & + & - \\
\hline Fluconazole & + & + & +++ & +++ \\
\hline
\end{tabular}

Where, - = Resistant, $+=1-10 \mathrm{~cm},++=10-20 \mathrm{~cm},+++=20-30 \mathrm{~cm}$.

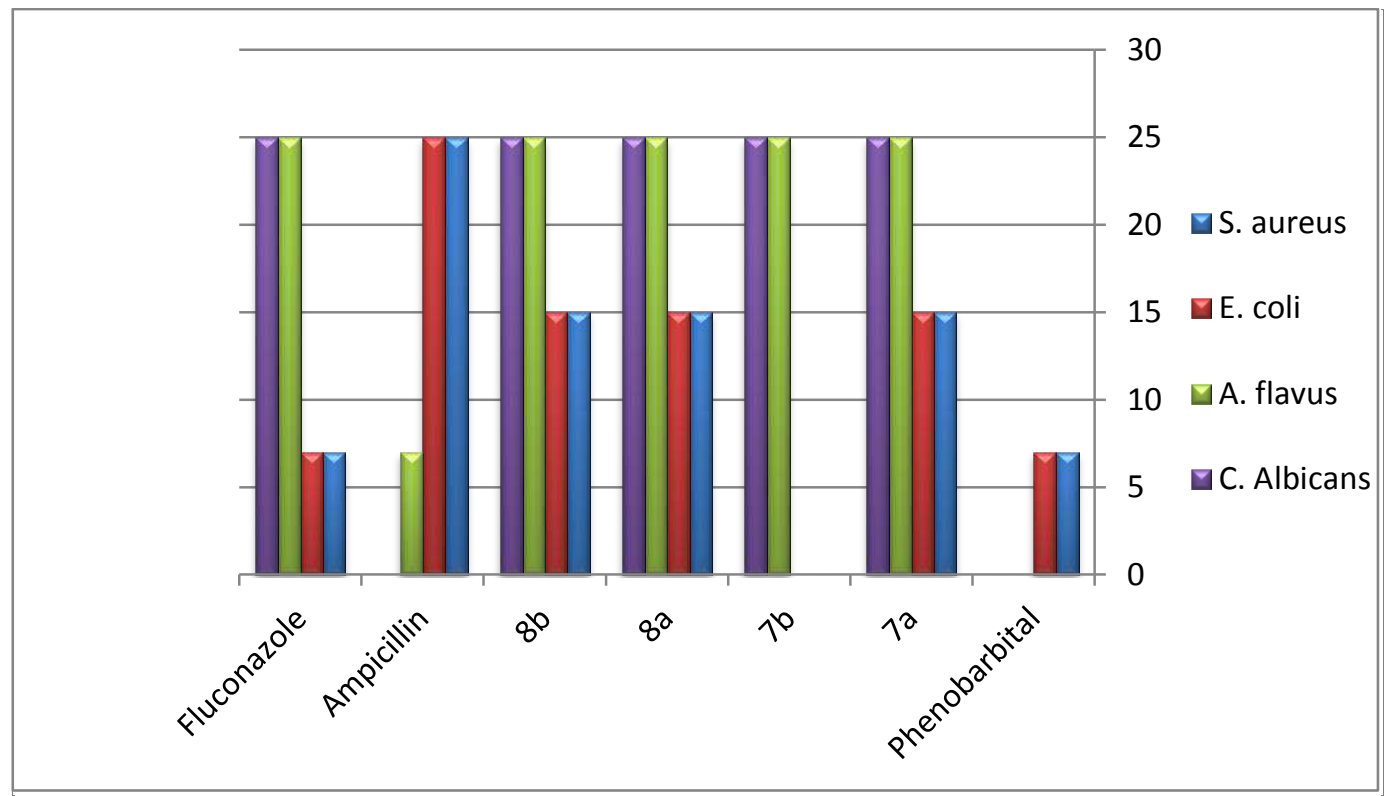

Figure1. Antimicrobial test of some prepared compounds $\mathbf{7}, \mathbf{8}_{(\mathbf{a}, \mathbf{b})}$

It is noted in the Table $\mathbf{3}$ and Figure $\mathbf{1}$ that the raw material represented by phenobarbital compound gave a low active against bacteria types, while in the fungi types it was inactive. All compounds 7,8 (a, b) gave high activity against types of fungi and equal to the standard compound (Fluconazole). The compounds (7a, 8a-b) also gave moderately active against all bacteria types, while the compound (7b) was inactive at (0.05 gm. IML).

\subsection{Molecular Modelling}


In molecular docking antimicrobial targets was selected based on known mechanism of action of marketed antibiotic drugs.

All synthesized compounds ( $7 \mathrm{a}, 7 \mathrm{~b}, 8 \mathrm{a}$, and $8 \mathrm{~b}$ ) were docked to the binding cavity 1 of DNA gyrase, topoisomerase and dihydropteroate synthetase of E. coli and $S$. aureus respectively. While antifungal in silico studies were carried out into the active sites of RNA polymerase, dihydrofolate reductase of A. flavus. Active sites of antifolates and dihydrofolates from $C$. albicans were inhibited by docking the synthesized compounds. Table 5 and 6 display the interaction energies in the form of MolDock score and number of protein-ligand interactions in the form of Re-rank score. Best established docked pose was selected based on MolDock score, number of hydrogen bond interactions, hydrophobic and Van der Waals (VdW) interactions [37].

Compound 7a behave as potential lead against S. aureus, as it showed maximum MolDock score for topoisomerase ATPase and DNA gyrase having three hydrogen bond interactions with DNA gyrase and ten hydrogen bond interactions with topoisomerase ATPase. Also showed best MolDock score against dihydrofolate reductase of C. albican with twelve hydrogen bond interactions. All these interactions involved oxygen, nitrogen, methylene hydrogens and hydrogen of diethyamino moieties [46].

Compound $7 \mathrm{~b}$ showed high MolDock score against RNA polymerase and dihydrofolate reductase of A. flavus. Thus, possessing best inhibiting potential for A. flavus. As these results were in accordance with in vitro antimicrobial activity. It had four hydrogen bond interactions to the active sites of RNA polymerase from oxygen and nitrogen atoms. With dihydrofolate reductase $7 \mathrm{~b}$ has six hydrogen bond interactions. $7 \mathrm{~b}$ also showed alkyl and pi-alkyl interactions with the bromo atom [38].

Compound 8a act as lead compound with highest MolDock score for inhibiting the growth of antifolates of A. flavus and dihydropteroate synthetase of $S$. aureus respectively. 8a showed six hydrogen bond interactions along with six different types of interactions comprising $\mathrm{VdW}$, hydrogen bond, pi-donor, pi-lone pair, and alkyl interactions with dihydropteroate synthetize. Antifolate showed total four hydrogen bond interactions [31].

Compound $8 \mathrm{~b}$ inhibited the growth of DNA gyrase of E. coli, having six hydrogen bond interactions involving oxygen and nitrogen atoms. While other interactions involved halogen, pi-donor and pi-alkyl [41].

Table 5. Molecular Docking against bacterial Strains

\begin{tabular}{|c|c|l|c|l|l|l|l|l|}
\hline & \multicolumn{6}{|c|}{ Molecular Docking against bacterial Strains } \\
\cline { 2 - 9 } Proteins & $\begin{array}{c}\text { Dihydropteroate } \\
\text { synthetase } \\
\text { From S. aureus }\end{array}$ & \multicolumn{2}{|c|}{$\begin{array}{c}\text { Topoisomerase } \\
\text { ATPase }\end{array}$} & $\begin{array}{c}\text { DNA Gyrase complex } \\
\text { with pyridine-3- } \\
\text { carboxamide }\end{array}$ & $\begin{array}{l}\text { DNA Gyrase } \\
\text { complex with } \\
\text { Clorobiocin }\end{array}$ \\
\hline Comp. & $\begin{array}{c}\text { MolDock } \\
\text { Score } \\
\text { (kcal/mol) }\end{array}$ & $\begin{array}{l}\text { Re- } \\
\text { rank } \\
\text { score }\end{array}$ & $\begin{array}{c}\text { MolDock } \\
\text { Score } \\
(\mathrm{kcal} / \mathrm{mol})\end{array}$ & $\begin{array}{l}\text { Re- } \\
\text { rank } \\
\text { score }\end{array}$ & $\begin{array}{c}\text { MolDock } \\
\text { Score } \\
(\mathrm{kcal} / \mathrm{mol})\end{array}$ & $\begin{array}{l}\text { Re-rank } \\
\text { score }\end{array}$ & $\begin{array}{c}\text { MolDock } \\
\text { Score } \\
(\mathrm{kcal} / \mathrm{mol})\end{array}$ & $\begin{array}{l}\text { Re- } \\
\text { rank } \\
\text { score }\end{array}$ \\
\hline $7 \mathrm{a}$ & -174.76 & 5.087 & -191.83 & - & -175.30 & 13.30 & -191.83 & - \\
\hline $7 \mathrm{~b}$ & -159.75 & -71.22 & -173.16 & - & -185.48 & -106.39 & -154.50 & -35.13 \\
\hline
\end{tabular}




\begin{tabular}{|c|l|l|l|l|l|l|l|l|}
\hline & & & & 110.77 & & & & \\
\hline $8 \mathrm{a}$ & -179.61 & -82.33 & -171.35 & - & -179.00 & -95.30 & -155.15 & -51.92 \\
\hline $8 \mathrm{~b}$ & -164.82 & -77.68 & -175.23 & - & -119.09 & & & \\
\hline Ampicillin & -100.33 & -45.22 & -201.43 & -82.62 & -110.27 & -69.02 & -88.04 & -56.85 \\
\hline
\end{tabular}

Table 6. Molecular Docking against Fungal Strains

\begin{tabular}{|c|c|c|c|c|c|c|c|c|}
\hline & \multicolumn{8}{|c|}{ Molecular Docking against Fungal Strains } \\
\hline \multirow[b]{2}{*}{ Proteins } & \multicolumn{4}{|c|}{ A. flavus } & \multicolumn{4}{|c|}{ C. albican } \\
\hline & \multicolumn{2}{|c|}{$\begin{array}{c}\text { Dihydrofolate } \\
\text { Reductase } \\
\text { with small inhibitor }\end{array}$} & \multicolumn{2}{|c|}{ RNA polymerase } & \multicolumn{2}{|c|}{$\begin{array}{l}\text { dihydrofolate } \\
\text { reductase }\end{array}$} & \multicolumn{2}{|c|}{$\begin{array}{l}\text { Dihydrofolate } \\
\text { Reductase }\end{array}$} \\
\hline Comp. & $\begin{array}{c}\text { MolDock } \\
\text { Score } \\
(\mathrm{kcal} / \mathrm{mol})\end{array}$ & $\begin{array}{l}\text { Re-rank } \\
\text { score } \\
(\mathrm{kcal} / \mathrm{mol})\end{array}$ & $\begin{array}{c}\text { MolDock } \\
\text { Score } \\
(\mathrm{kcal} / \mathrm{mol})\end{array}$ & $\begin{array}{l}\text { Re-rank } \\
\text { score } \\
(\mathrm{kcal} / \mathrm{mol})\end{array}$ & $\begin{array}{c}\text { MolDock } \\
\text { Score } \\
(\mathrm{kcal} / \mathrm{mol})\end{array}$ & $\begin{array}{l}\text { Re-rank } \\
\text { score } \\
(\mathrm{kcal} / \mathrm{mol})\end{array}$ & $\begin{array}{c}\text { MolDock } \\
\text { Score } \\
(\mathrm{kcal} / \mathrm{mol})\end{array}$ & $\begin{array}{l}\text { Re-rank } \\
\text { score } \\
(\mathrm{kcal} / \mathrm{mol})\end{array}$ \\
\hline $7 \mathrm{a}$ & -235.13 & -175.90 & -192.76 & -131.19 & -144.09 & -49.28 & -228.72 & -95.72 \\
\hline $7 \mathrm{~b}$ & -237.13 & -150.38 & -194.60 & -126.30 & -160.29 & -76.52 & -170.68 & -96.80 \\
\hline $8 \mathrm{a}$ & -230.31 & -169.44 & -188.51 & -106.55 & -161.40 & -92.40 & -172.16 & -23.26 \\
\hline $8 \mathrm{~b}$ & -155.96 & -77.22 & -178.52 & -95.54 & -174.93 & -81.82 & -153.78 & -40.75 \\
\hline Fluconazole & \begin{tabular}{|l|}
-109.58 \\
\end{tabular} & \begin{tabular}{|l|}
-90.09 \\
\end{tabular} & -107.68 & -75.12 & -106.44 & -81.51 & -85.20 & $\begin{array}{l}-61.84 \\
\end{array}$ \\
\hline
\end{tabular}




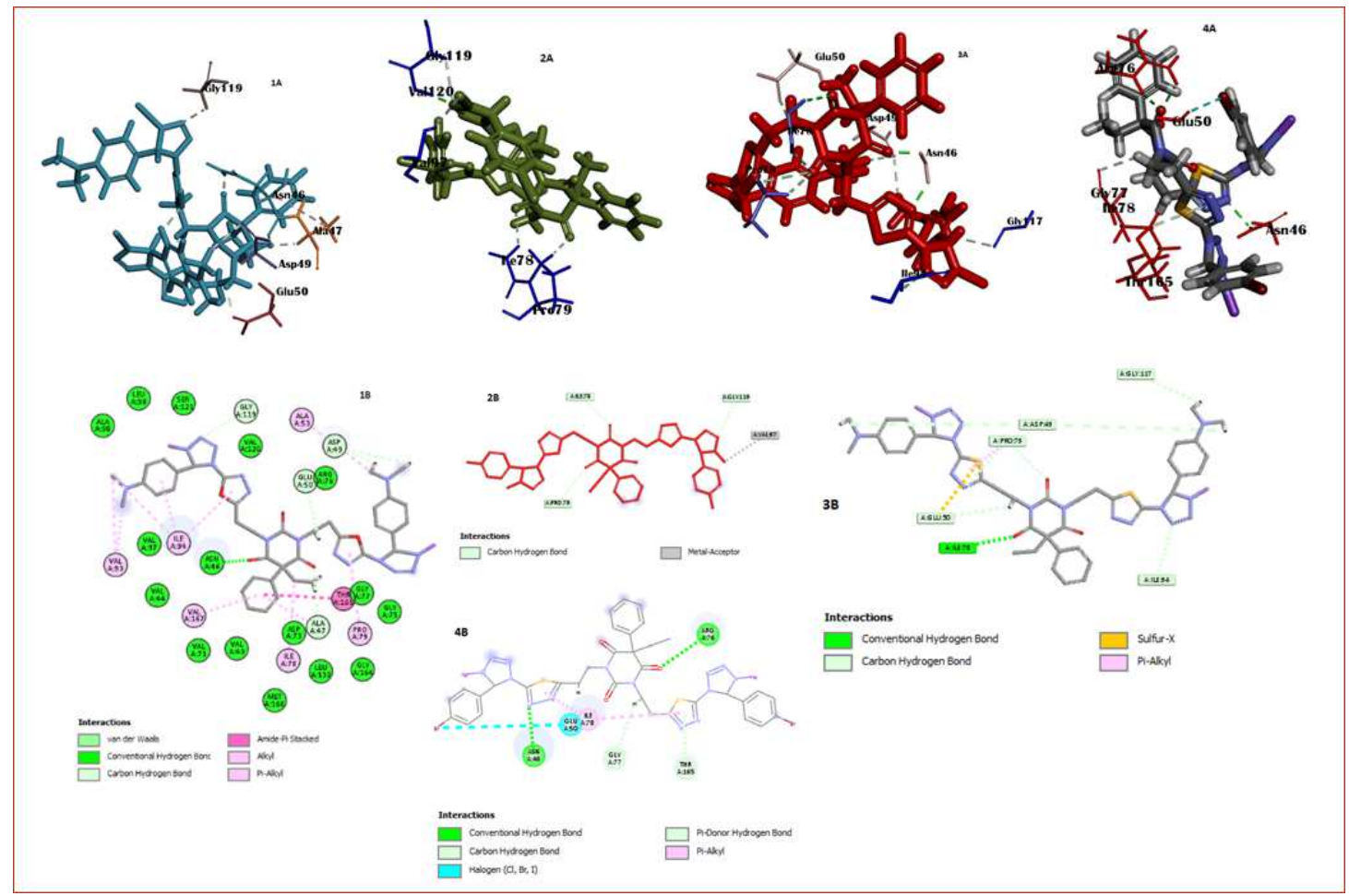

Figure 2. Three-dimensional view of compounds $7 \mathrm{a}-8 \mathrm{~b}$ from $1 \mathrm{~A}-4 \mathrm{~A}(1 \mathrm{~A}=7 \mathrm{a}, 2 \mathrm{~A}=7 \mathrm{~b}$, $3 \mathrm{~A}=8 \mathrm{a}, 4 \mathrm{~A}=8 \mathrm{~b}$ ) into the binding cavity of $6 \mathrm{f} 86,2 \mathrm{D}$ view by Discovery studio of compounds $7 \mathrm{a}-8 \mathrm{~b}$ from $1 \mathrm{~B}-4 \mathrm{~B}(1 \mathrm{~B}=7 \mathrm{a}, 2 \mathrm{~B}=7 \mathrm{~b}, 3 \mathrm{~B}=8 \mathrm{a}, 4 \mathrm{AB}=8 \mathrm{~b})$ for $6 \mathrm{f} 86$ (DNA Gyrase of E. coli)

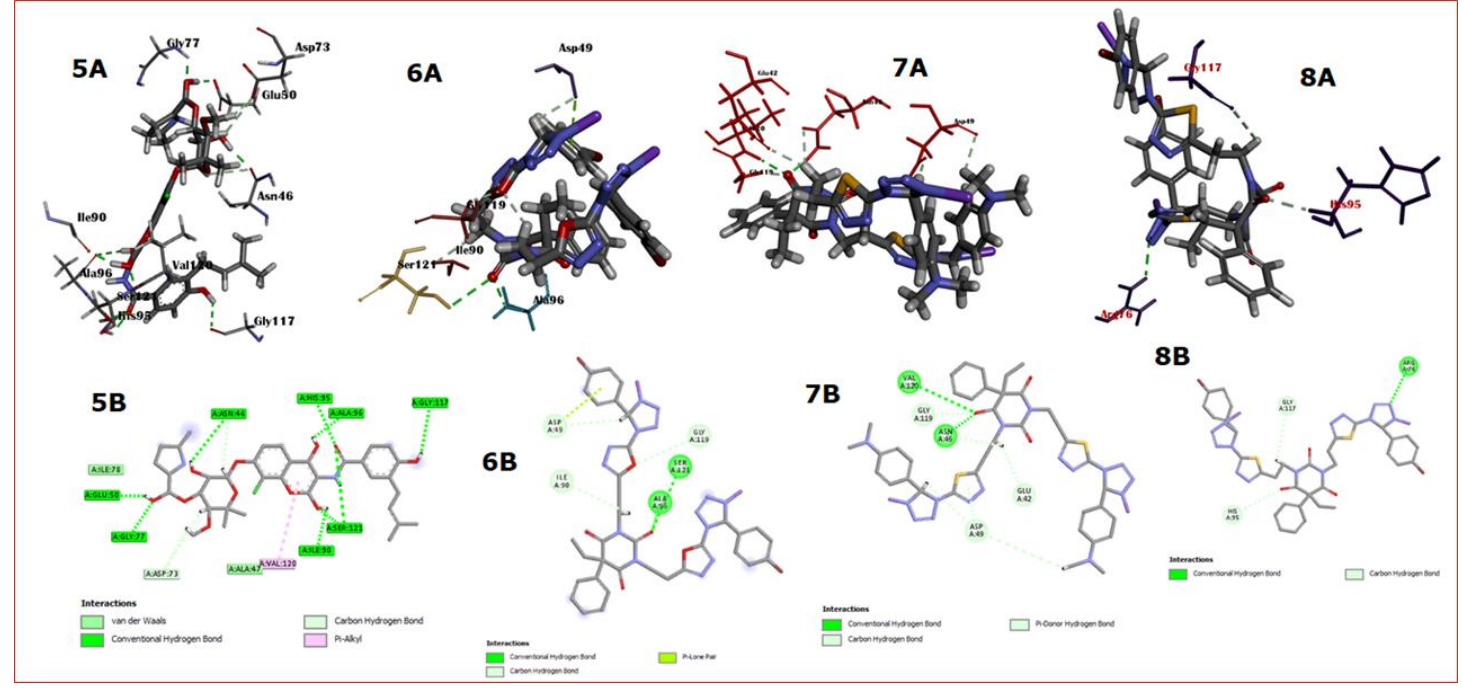

Figure 3. Three-dimensional view of compounds $7 \mathrm{a}-8 \mathrm{~b}$ from $5 \mathrm{~A}-8 \mathrm{~A}$ into the binding cavity of $1 \mathrm{kzn}, 2 \mathrm{D}$ view by Discovery studio of compounds $7 \mathrm{a}-8 \mathrm{~b}$ from $5 \mathrm{~B}-8 \mathrm{~B}$ for $1 \mathrm{kzn}$ (DNA Gyrase of S. aureus). 


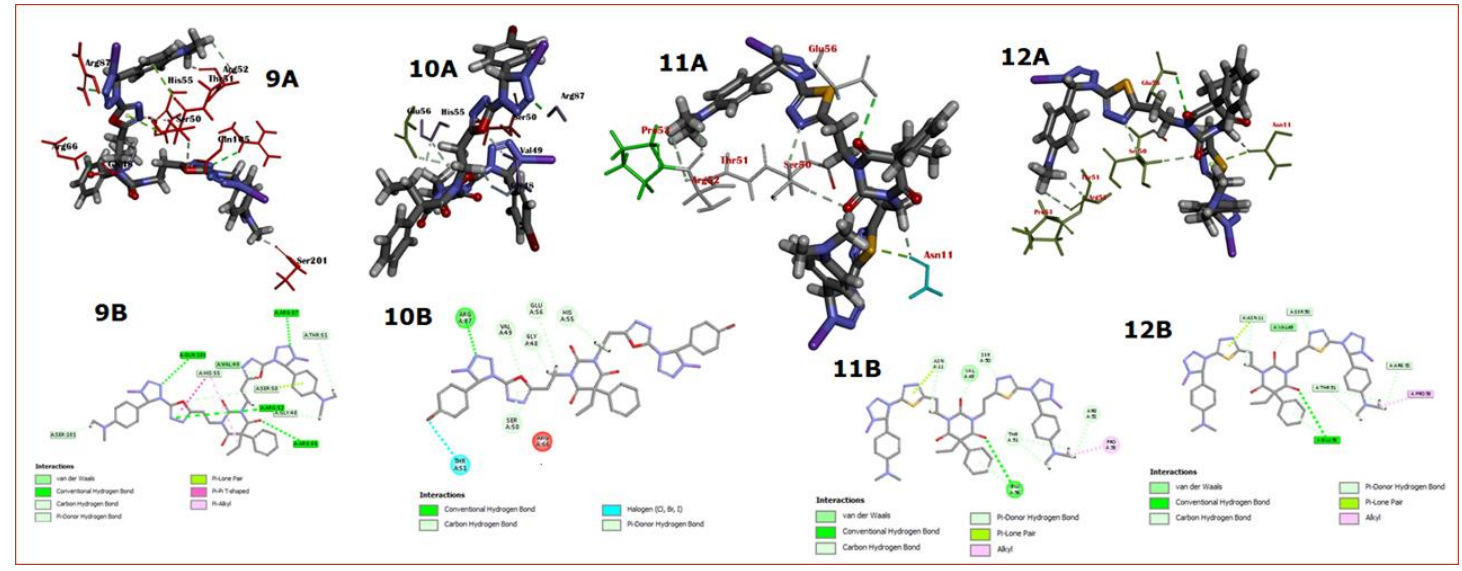

Figure 4. Three-dimensional view of compounds $7 \mathrm{a}-8 \mathrm{~b}$ from $9 \mathrm{~A}-12 \mathrm{~A}$ into the binding cavity of $1 \mathrm{ad} 4,2 \mathrm{D}$ view by Discovery studio of compounds $7 \mathrm{a}-8 \mathrm{~b}$ from $9 \mathrm{~B}-12 \mathrm{~B}$ for $1 \mathrm{ad} 4$ (dihydropteroate synthetized of S. aureus).

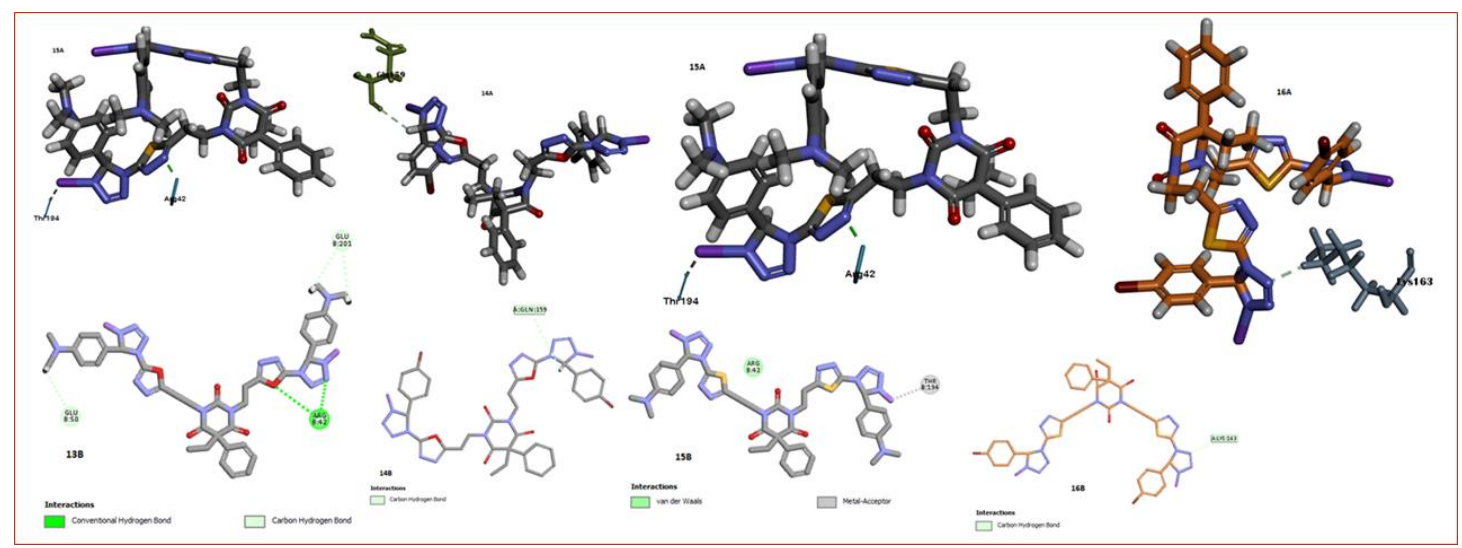

Figure 5. Three-dimensional view of compounds $7 \mathrm{a}-8 \mathrm{~b}$ from $13 \mathrm{~A}-16 \mathrm{~A}$ into the binding cavity of 3ttz, 2D view by Discovery studio of compounds 7a-8b from 13B-16B for 1ad4 (topoisomerase ATPase of $S$. aureus)

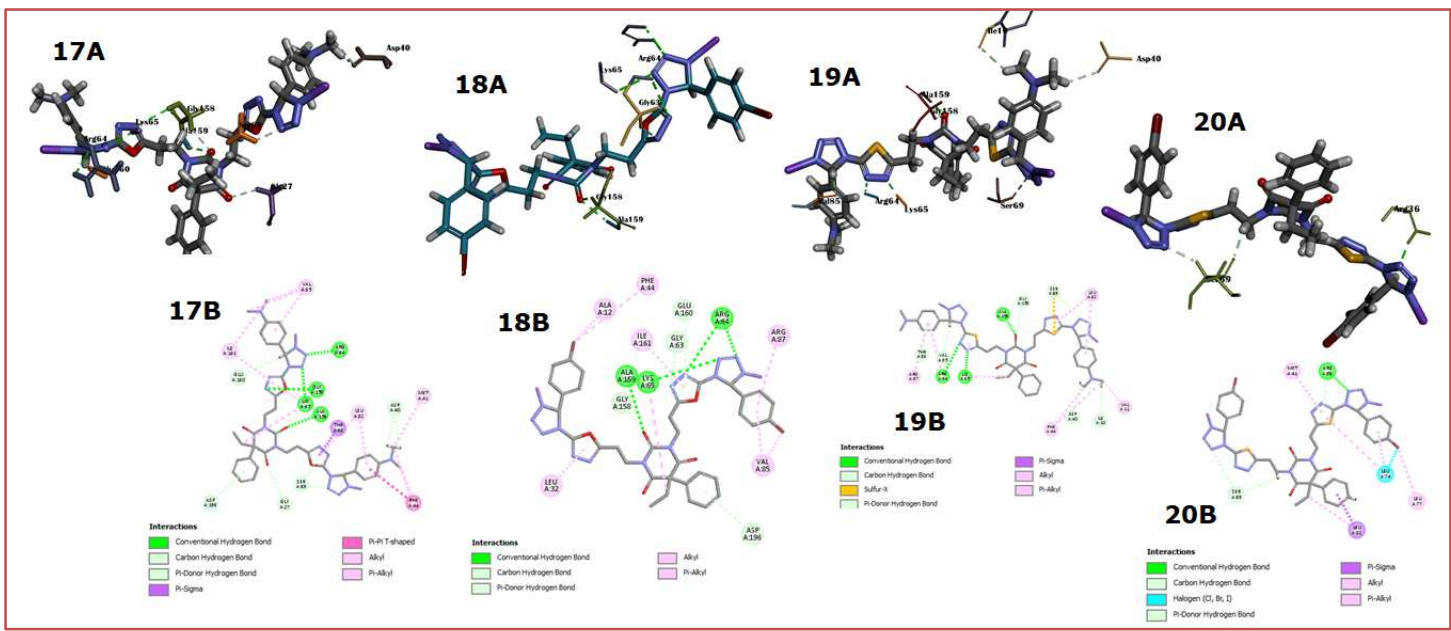

Figure 6. Three-dimensional view of compounds $7 \mathrm{a}-8 \mathrm{~b}$ from $17 \mathrm{~A}-20 \mathrm{~A}$ into the binding cavity of 6drs, 2D view by Discovery studio of compounds $7 \mathrm{a}-8 \mathrm{~b}$ from $17 \mathrm{~B}-20 \mathrm{~B}$ for $6 \mathrm{drs}$ (dihydrofolate reductase of A. flavus) 


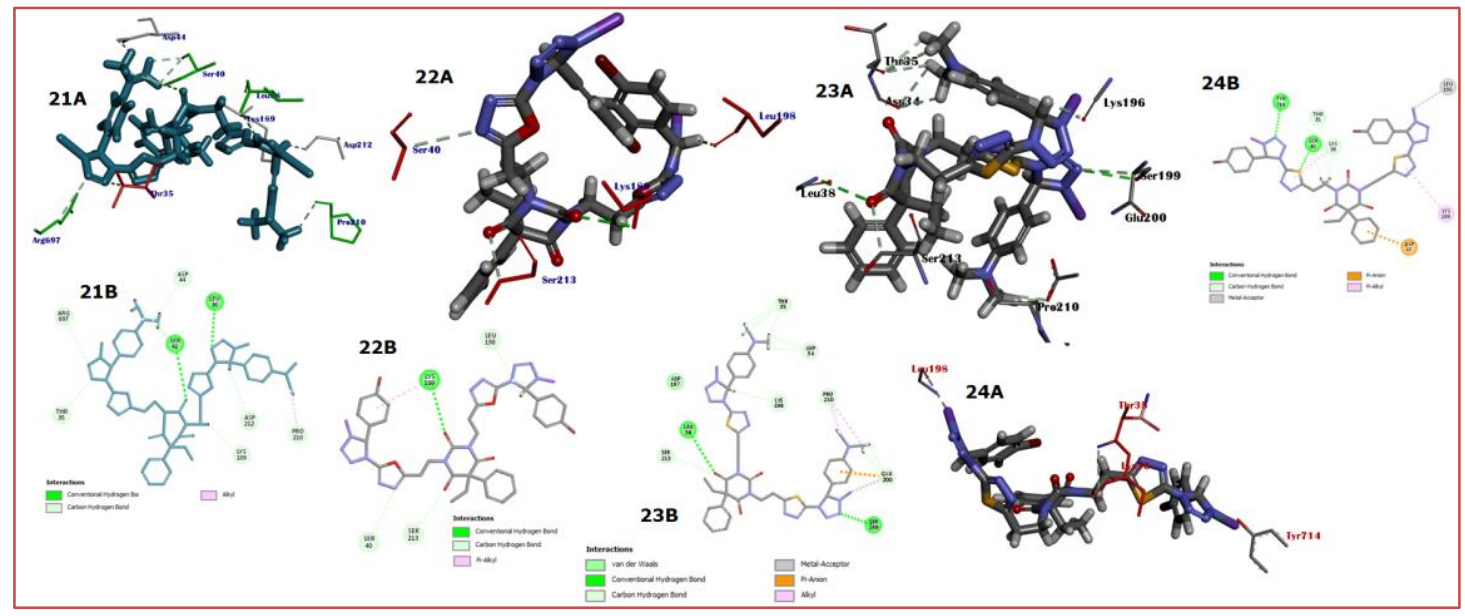

Figure 7. Three-dimensional view of compounds $7 \mathrm{a}-8 \mathrm{~b}$ from $21 \mathrm{~A}-24 \mathrm{~A}$ into the binding cavity of $6 \mathrm{drs}, 2 \mathrm{D}$ view by Discovery studio of compounds $7 \mathrm{a}-8 \mathrm{~b}$ from $21 \mathrm{~B}-24 \mathrm{~B}$ for homology modelled protein (RNA polymerase of A. flavus).

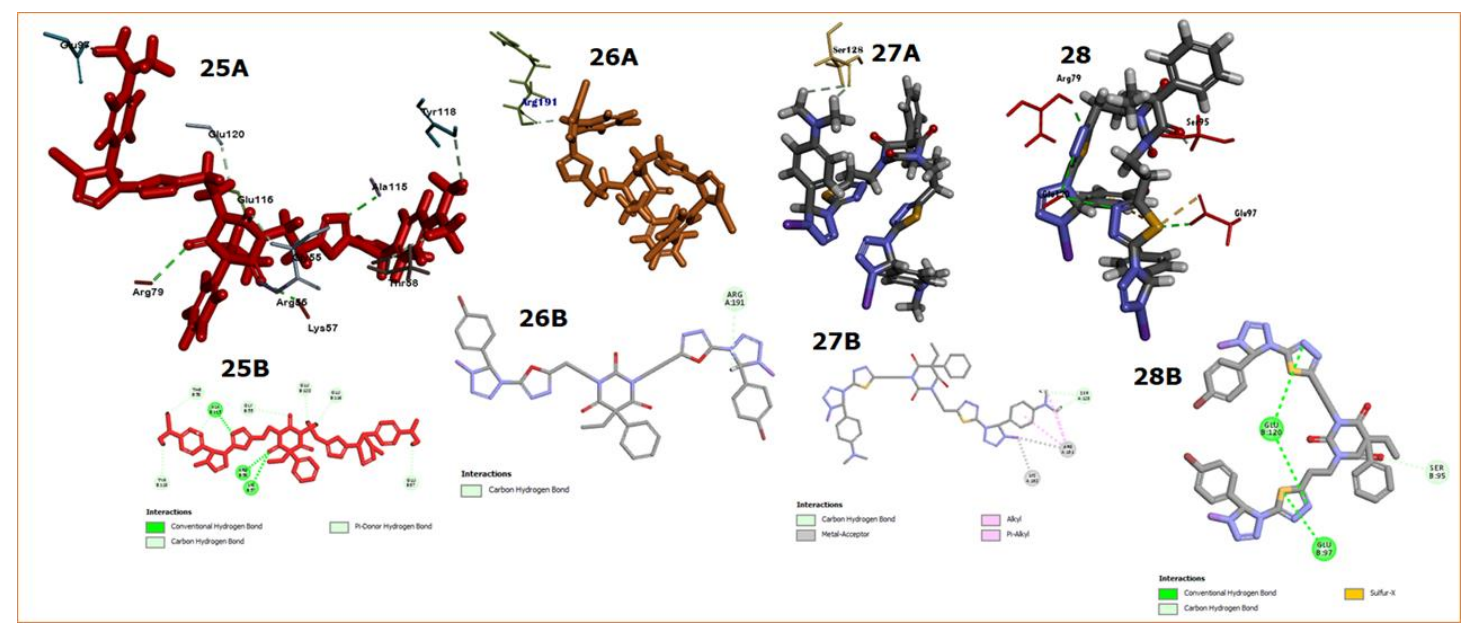

Figure 8. Three-dimensional view of compounds $7 \mathrm{a}-8 \mathrm{~b}$ from $25 \mathrm{~A}-28 \mathrm{~A}$ into the binding cavity of $6 \mathrm{drs}, 2 \mathrm{D}$ view by Discovery studio of compounds $7 \mathrm{a}-8 \mathrm{~b}$ from $25 \mathrm{~B}-28 \mathrm{~B}$ for 1ai9 (dihydrofolate reductase of C. albicans).

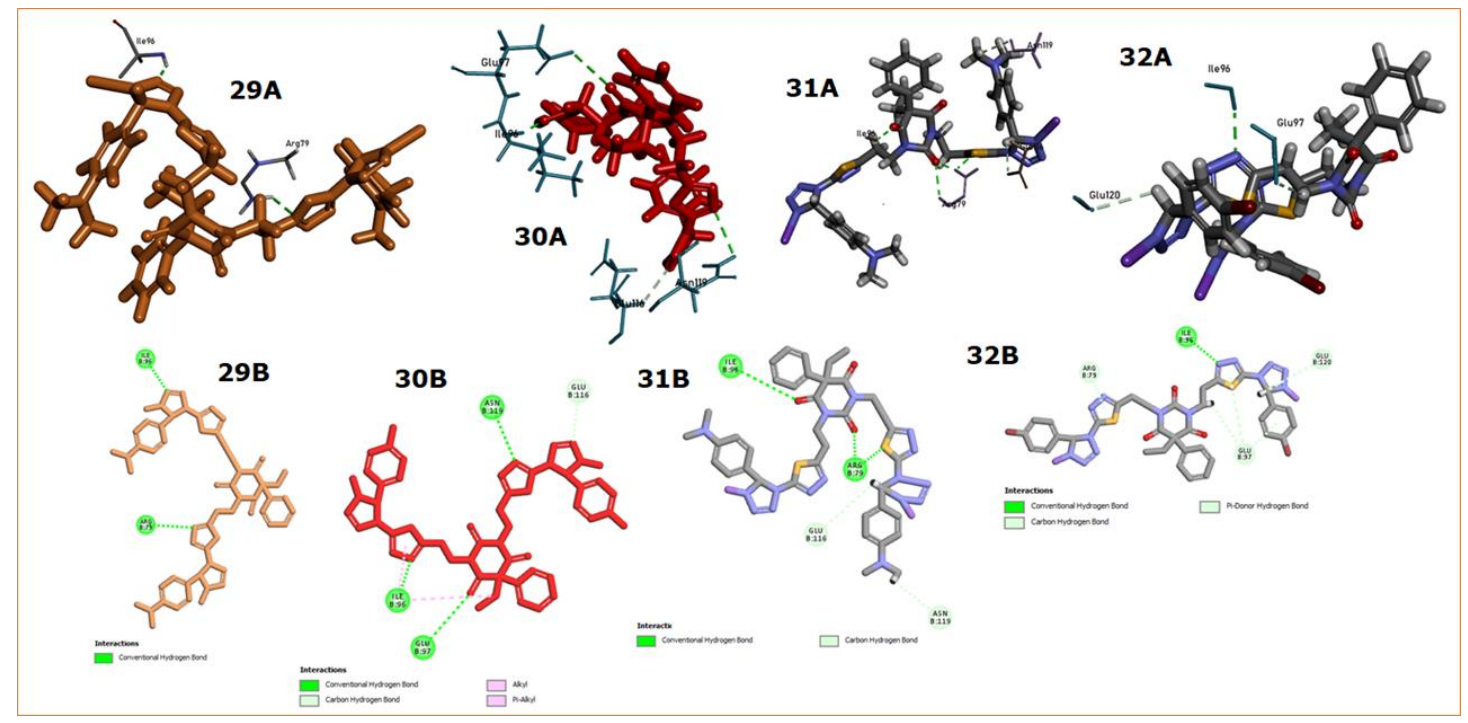


Figure 9. Three-dimensional view of compounds $7 \mathrm{a}-8 \mathrm{~b}$ from $29 \mathrm{~A}-32 \mathrm{~A}$ into the binding cavity of 6drs, 2D view by Discovery studio of compounds $7 \mathrm{a}-8 \mathrm{~b}$ from $29 \mathrm{~B}-32 \mathrm{~B}$ for 4 hof (dihyrofolate reductase of C. albicans).

\section{Conclusions}

Barbituric acid and tetrazole or tetrazoline compounds are important in various medical applications. Phenobarbital as raw material was used to make a series of barbituric acid derivatives containing 1,2,3,4-Tetrazoline moiety. The resulting compounds were characterized by various techniques as (Melting point, TLC, FT-IR, ${ }^{1} \mathrm{H}-\mathrm{NMR}$ and ${ }^{13} \mathrm{C}-\mathrm{NMR}$ ). In the antifungal test, all results were given high activity against types of fungi and equal to the standard compound (Fluconazole), however in the antibacterial test; they showed a wide range of activities and low values when compared to the standard compound (Ampicillin). All these results corroborate the in vitro antimicrobial activity also, as the compounds which were inactive in antimicrobial activity also showed less MolDock score in in silco study also. As these compounds showed best hydrophobic interactions along with hydrogen bond thus hypothesizing that these interactions were important for stabilization of protein ligand complex [47]. After antimicrobial docking simulation, we concluded that compound 7a can be antimicrobial lead compound as inhibitor of DNA and nucleic acid synthesis [48].

\section{Acknowledgment}

All thanks and appreciation to the pharmacist Tuqa S. Al-Amin for completing the biological applications.

\section{Conflicts of interest}

There aren't any conflicts to report.

\section{References}

[1] David W, Thomas L and Lippincott, 2002 Foye's Principles of Medicinal Chemistry (5th ed) Williams \& Wilkins p. 367.

[2] Hayder K A, Ehab K O, Farked W S, Hayder A S and Ali J R, Synthesis and Study Antimicrobial Activity of Polybarbiturate Contain Triazole Ring, International Conference on Materials Engineering \& Science,2020, 2213, 1-6.

[3] Tsonko K, Rumyana B, Rüediger W S, HeikeM, Iris M O, Michael S, William S S and Bojidarka B K, Novel codeinone derivatives via Michael addition of barbituric acids, Tetrahedron: Asymmetry, 2009, 20, 327-334.

[4] Ali J R, Ezzat H Z and Emad A J Al-Mulla, Synthesis of some novel barbital derivatives based on Carbohydrate as $\alpha$-glucosidase inhibitors, Research J. Pharm. and Tech., 2019, 12, 1145-1154.

[5] Reddy Y T, Sekhar K R, Sasi N, Reddy P N, Freeman M L and Crooks P A, Antiangiogenic properties of substituted $(\mathrm{Z})-( \pm)-2-(\mathrm{N}-b e n z y l i n d o l-3-y l m e t h y l e n e)$ quinuclidin -3-ol/one analogs and their derivatives, Bioorganic \& medicinal chemistry letters, 2010, 20, 7323-7326. 
[6] Kamran T M, Maximilian N K, Abel M M, Malahat M K, Atash V G and Armando J L P, Barbituric acids as a useful tool for the construction of coordination and supramolecular compounds, Coordination Chemistry Reviews, 2014, 265, 1-37.

[7] Konstantin A K, Pavel V D, Yan V Z, Tatiana V T and Victor N K, Hydride transfer reactions of 5-(2-alkohybenzylidene) barbituric acids: Synthesis of 2,4,6trioxoperhydropyrimidine-5-spiro-3'-chromanes, Tetrahedron, 2017, 73, 542-549.

[8] Humberto C G, Mariana T C C, Howell G M E and Luiz F C O, Vibrational and structural properties of barbiturate anions in supramolecular compounds, Vibrational Spectroscopy, 2016, 86, 134-142.

[9] Thetford D, Chorlton A P and Hardman J, Synthesis and properties of some polycyclic barbiturate pigments, Dyes and Pigments, 2003, 59, 185-191.

[10] Louis D Q, John A T, Fundamentals of heterocyclic chemistry (10 ed) John Wiley, 2010, p.112.

[11] María J A, Luis R D, Patricia P, Renato C, A theoretical study on the regioselectivity of 1,3-dipolar cycloadditions using DFT-based reactivity indexes, Tetrahedron, 2004, 60, 11503-11509.

[12] Jia-Qi L, Rong-Zhen L, Wan-Jian D and Ying C, Highly Efficient and Site-Selective [3+ 2] Cycloaddition of Carbene-Derived Ambident Dipoles with Ketenes for a Straightforward Synthesis of Spiro-Pyrrolidones, J. Org. Chem., 2007, 72, 6266-6269.

[13] Khitam T A Al-Sultani, Suaad M H Al-Majidi and Oday H R Al-Jeilawi, Synthesis, Identification and Evaluation Biological Activity for Some New Triazole, Triazoline and Tetrazoline Derivatives From 2-Mercapto-3- phenyl-4(3H)Quinazolinone, Iraqi Journal of Science, 2016, 57, 295-308.

[14] Popat B M and Bhaskar V, A Facile Synthesis, Characterization and In-Vitro Antiinflammatory Activity of Novel OF N-substituted Tetrazoles, Journal of Optoelectronics and Biomedical Materials, 2011, 3, 87-93.

[15] Rajasekaran A and Thampi P P, Synthesis and antinociceptive activity of some substituted-\{5-[2-(1,2,3,4-tetrahydrocarbazol-9-yl)ethyl]tetrazol-1-yl $\}$ alkanones, Eur., J. Med. Chem., 2005, 40, 1359-1364.

[16] Jan A, Karel W, Jiř́ K, Jarmila K, A Note on the Antitubercular Activities of 1-Aryl-5benzylsulfanyltetrazoles, Arch. Pharm. Chem. Life Sci., 2005, 338, 385-389.

[17] Shanmugam G, Bhakiaraj D, Elavarasan S., Elavarasan T and Gopalakrishan M, Benign by Design Synthesis of Novel $1 H$-Tetrazoles: Spectral Characterization and Antibacterial Activities, Chemical Science Transactions, 2013, 2, 1304-1311.

[18] Clayden J, Nick G, Stuart W and Peter Wothers ,"Organic chemistry", 2007, p.1168.

[19] Sonwane S K and Srivastava S D, Synthesis and Antimicrobial Activity of Some 2-[(4Substituted-Phenyl-3-Chloro-Azetidin-2-One)-5-(2'-Methylamino-4-Phenyl-1',3'-Thiazolyl-]1, 3,4-Thiadiazoles, Journal of Sciences, Islamic Republic of Iran, 2009, 20, 227-232. 
[20] Arif M, Hacer B , Yakup S, Mustafa E and Neslihan D, Synthesis of novel Azol-blactam derivatives starting from phenyl piperazine and investigation of their antiurease activity and antioxidant capacity comparing with their molecular docking studies, Journal of Molecular Structure, 2019, 1189, 279-287.

[21] Ashish K S, Prem Y, Krishna S and Jagdish P, Synthesis, characterization, biological and electrochemical investigation of copper (II) complexes containing 4-chloro-2-[2, 6diisopropylphenylimino) methyl] phenol Schiff base ligand and aromatic diinines, Chemical Data Collections, 2021, 32, 100659.

[22] Shreya M, Nishith M, Muddukrishnaiah K, Mayank J, Madhusudan S and Angshuman R C, Bhaskar B, Synthesis, Structure, Polyphenol Oxidase Mimicking and Bactericidal Activity of a Zinc-Schiff Base Complex, Polyhedron,2021, 194, 1-25.

[23] Carmen M S, Mona F A and Asmaa A H, Synthesis, Structure Characterization and Biological Activity of Selected Metal Complexes of Sulfonamide Schiff Base as a Primary Ligand and some Mixed Ligand Complexes with Glycine as a Secondary Ligand, Journal of Molecular Structure, 2016, 1134, 208-216.

[24] Fahimeh R, Mohammad A A and Reza K, Design and synthesis of $\mathrm{Fe}_{3} \mathrm{O}_{4} @ \mathrm{SiO}_{2}$ /azacrown ether-Cu(II) as a novel and highly efficient magneticnanocomposite catalyst for the synthesis of 1,2,3-triazoles, 1-substituted $1 \mathrm{H}$-tetrazoles and 5-substituted $1 \mathrm{H}$-tetrazoles in green solvents, Inorganica Chimica Acta, 2019, 489, 8-18.

[25] Saira M, Qamar-un-nisa T, Xin Y and Jian-Guo Z, Nitro-tetrazole based high performing explosives: Recent overview of synthesis and energetic properties, Defence Technology, 2021, 9, 1-16.

[26] Celal T Z, Ozlem T A, Mustafa A and Fatma K O, Synthesis, antimicrobial activity, density functional modelling and molecular docking with COVID-19 main protease studies of benzoxazole derivative: 2-(p-chloro-benzyl)-5-[3-(4-ethly-1-piperazynl) propionamido]benzoxazole, Journal of Molecular Structure, 2021, 5, 1-35.

[27] Ego rove N S , Antibiotics Scientific Approach. Mir publishers, Moscow, 1985.

[28] Mahmood M F, Ezzat H Z and Majed J M, Synthesis and Antimicrobial Activity of Some New Barbituric Acid Derivatives Containing Thiazole Moiety from Sulfadiazine, Nano Biomed. Eng., 2019, 1, 124-137.

[29] Jin Z, Du X, Xu Y, Deng Y, Liu M., Zhao Y, Zhang B, Li X, Zhang L, Peng C J N, Structure of M pro from SARS-CoV-2 and discovery of its inhibitors, 2020, 582, (7811), 289293.

[30] Kim Y, Jedrzejczak R, Maltseva N I, Wilamowski M, Endres M, Godzik A, Michalska K, Joachimiak A J P S, Crystal structure of Nsp15 endoribonuclease NendoU from SARSCoV-2. 2020, 29, (7), 1596-1605.

[31] Reddy N N, Hung S J, Swamy M K, Sanjeev A, Rao V S, Rohini R, Raju A K, Bhaskar K, Hu A, Reddy P M J M, Synthesis and Rational Design of New Appended 1, 2, 3-Triazoleuracil Ensembles as Promising Anti-Tumor Agents via In Silico VEGFR-2 Transferase Inhibition., 2021, 26, (7). 
[32] Ayik R P, Docking studies of Physalis peruviana ethanol extract using molegro virtual docker on insulin tyrosine kinase receptor as antidiabetic agent, International Current Pharmaceutical Journal, 2014, 3(5), 265-269.

[33] Bernardi D M, Marchi J P, Araújo C d S A, do Nascimento V R, de Souza Lima D, Wietzikoski S, Ferro M M, Miyoshi E, dos Reis Lívero F A, Seixas F A V J R, Society, Development, Dopamine docking studies of biologically active metabolites from Curcuma longa L., Research, Society and Development, 2021, 10, 7.

[34] Thambidurai P, Raja V, Ashokapuram Selvam S, Kannaiyan M, Shanmugam, Prioritization of Drugs for Fungal Keratitis Eye Infections: An In-Silico Analysis, Applied Sciences, 2019, 9, (12), 2485.

[35] Benjamin W, Andrej S, Comparative protein structure modeling using MODELLER, Curr Protoc Bioinformatics, 2016, 54, (1), 5.6. 1- 5.6.37

[36] Nur H Z, Lamkok W, Nurul I H, Molecular Docking Study of the Interactions between Plasmodium falciparum Lactate Dehydrogenase and 4-aminoquinoline Hybrids, Sains Malaysiana, 2020, 49, (8), 1905-1913.

[37] Divya J, Trishang U, Shreshtha S, Aishwarya G, Palugulla B R, Anuraj N and Sanjeev K $\mathrm{S}$, Design of novel JAK3 Inhibitors towards Rheumatoid Arthritis using molecular docking analysis, Bioinformation, 2019, 15, (2), 68-78.

[38] Gul Z, Nusrat S, Uzm A, Naila R, Shagufta P, Zaheer A, Copper-catalyzed one-pot relay synthesis of anthraquinone based pyrimidine derivative as a probe for antioxidant and antidiabetic activity, Journal of Molecular Structure, 2021, 1227, 129668.

[39] Sevki A, Volkan E, Iqra S, Azhar R, Muhammad A, Identification of potent COVID-19 main protease (Mpro) inhibitors from natural polyphenols: an in silico strategy unveils a hope against CORONA., preprints, 2020. 2020030333.

[40] Jawaid A, Ahsan A K , Zulphikar A, Rafi H, Shahar M Y, Structure-activity relationship (SAR) study and design strategies of nitrogen-containing heterocyclic moieties for their anticancer activities, Eur J Med Chem., 2017, 125, 143-189.

[41] Nusrat S, Uzma A, Nazia Y, Jallat K, Ahmad K, Kaynat S, Maryam R, Naila R, Rashid A, Irum J, Sadia N, Muhammad B, Structure-based experimental and theoretical analysis of Ricinus communis for their HepG2 human carcinoma cell line inhibitors, Process Biochemistry, 2021, 104, 152-160.

[42] Adem S, Eyupoglu V, Sarfraz I, Rasul A, Zahoor A F, Ali M, Abdalla M, Ibrahim I M, Elfiky, Caffeic acid derivatives (CAFDs) as inhibitors of SARS-CoV-2: CAFDs-based functional foods as a potential alternative approach to combat COVID-19, Phytomedicine, $2021,85,153310$.

[43] Arshad, Uzma, Sibtain Ahmed, Nusrat Shafiq, Zaheer Ahmad, Aqsa Hassan, Naseem Akhtar, Shagufta Parveen, and Tahir Mehmood, Structure-Based Designing, Solvent Less Synthesis of 1, 2, 3, 4-Tetrahydropyrimidine-5-carboxylate Derivatives: A Combined In Vitro and In Silico Screening Approach, Molecules, 2021, 26, (15), 4424. 
[44] René $\mathrm{T}$ and Mikael $\mathrm{H}$, Christensen, MolDock: a new technique for high-accuracy molecular docking, J. Med. Chem., 2006, 49, (11), 3315-3321.

[45] Vraj R S, Jaydip D B, Gautam M P, In silico approach: docking study of oxindole derivatives against the main protease of COVID-19 and its comparison with existing therapeutic agents, J. Basic Clin Physiol Pharmacol, 2021, 32, (3), 197-214.

[46] Salam P Si and Bolin K K, Molecular docking studies of quercetin and its analogues against human inducible nitric oxide synthase, SpringerPlus, 2012, 1, (1), 1-10.

[47] Rohan P, Suranjana D, Ashley S, Lumbani Y, Akulapalli S, Ashok K V, Optimized hydrophobic interactions and hydrogen bonding at the target-ligand interface leads the pathways of drug-designing, PLoS One, 2010, 5, (8), 12029.

[48] Maria J A, Hugo J C F, Ana F T C, Anabela F S, Liliana G O, Sara R M O, Rui M V A, Manuela P, Isabel C F R F, Docking studies in target proteins involved in antibacterial action mechanisms: Extending the knowledge on standard antibiotics to antimicrobial mushroom compounds, Molecules, 2014, 19, (2), 1672-1684. 